\title{
P(3HB) Based Magnetic Nanocomposites: Smart Materials for Bone Tissue Engineering
}

\author{
Everest Akaraonye, ${ }^{1}$ Jan Filip, ${ }^{2}$ Mirka Safarikova, ${ }^{3}$ Vehid Salih, ${ }^{4,5}$ Tajalli Keshavarz, \\ Jonathan C. Knowles, ${ }^{4,6}$ and Ipsita Roy ${ }^{1}$ \\ ${ }^{1}$ Applied Biotechnology Research Group, Department of Life Sciences, Faculty of Life Sciences, University of Westminster, \\ London W1W 6UW, UK \\ ${ }^{2}$ Regional Centre of Advanced Technologies and Materials, Palacký University, Šlechtitelù 27, 78371 Olomouc, Czech Republic \\ ${ }^{3}$ Biology Centre, AS CR ISB, Department of Nanobiotechnology, Na Sadkach 7, 37005 Ceske Budejovice, Czech Republic \\ ${ }^{4}$ Department of Biomaterials and Tissue Engineering, Eastman Dental Institute, University College London, London, WC1X 8LD, UK \\ ${ }^{5}$ Plymouth University Peninsula Schools of Medicine and Dentistry, Portland Square, Drake Circus, Plymouth, Devon PL4 8AA, UK \\ ${ }^{6}$ WCU Research Centre of Nanobiomedical Science, Dankook University, San No. 29, Anseo-dong, Dongnam-gu, \\ Cheonan-si, Chungnam, Republic of Korea
}

Correspondence should be addressed to Ipsita Roy; royi@wmin.ac.uk

Received 12 January 2016; Revised 12 May 2016; Accepted 31 August 2016

Academic Editor: Jean M. Greneche

Copyright (C) 2016 Everest Akaraonye et al. This is an open access article distributed under the Creative Commons Attribution License, which permits unrestricted use, distribution, and reproduction in any medium, provided the original work is properly cited.

The objective of this work was to investigate the potential application of Poly(3-hydroxybutyrate)/magnetic nanoparticles, $\mathrm{P}(3 \mathrm{HB}) / \mathrm{MNP}$, and Poly(3-hydroxybutyrate)/ferrofluid $(\mathrm{P}(3 \mathrm{HB}) / \mathrm{FF})$ nanocomposites as a smart material for bone tissue repair. The composite films, produced using conventional solvent casting technique, exhibited a good uniform dispersion of magnetic nanoparticles and ferrofluid and their aggregates within the $\mathrm{P}(3 \mathrm{HB})$ matrix. The result of the static test performed on the samples showed that there was a $277 \%$ and $327 \%$ increase in Young's modulus of the composite due to the incorporation of MNP and ferrofluid, respectively. The storage modulus of the $\mathrm{P}(3 \mathrm{HB}) \mathrm{MNP}$ and $\mathrm{P}(3 \mathrm{HB}) / \mathrm{FF}$ was found to have increased to $186 \%$ and $103 \%$, respectively, when compared to neat $\mathrm{P}(3 \mathrm{HB})$. The introduction of $\mathrm{MNP}$ and ferrofluid positively increased the crystallinity of the composite scaffolds which has been suggested to be useful in bone regeneration. The total amount of protein absorbed by the $\mathrm{P}(3 \mathrm{HB}) / \mathrm{MNP}$ and $\mathrm{P}(3 \mathrm{HB}) / \mathrm{FF}$ composite scaffolds also increased by $91 \%$ and $83 \%$, respectively, with respect to neat $\mathrm{P}(3 \mathrm{HB})$. Cell attachment and proliferation were found to be optimal on the $\mathrm{P}(\mathrm{HB}) / \mathrm{MNP}$ and $\mathrm{P}(3 \mathrm{HB}) / \mathrm{FF}$ composites compared to the tissue culture plate (TCP) and neat $\mathrm{P}(3 \mathrm{HB})$, indicating a highly compatible surface for the adhesion and proliferation of the MG63 cells. Overall, this work confirmed the potential of using $\mathrm{P}(3 \mathrm{HB}) / \mathrm{MNP}$ and $\mathrm{P}(3 \mathrm{HB}) / \mathrm{FF}$ composite scaffolds in bone tissue engineering.

\section{Introduction}

Recently, interest in tissue engineering and its solutions have increased significantly with bone and cartilage regeneration by autogenous cell delivery or tissue regeneration becoming one of the most promising modes of orthopaedic surgery. In particular, scaffolds have become fundamental tools in bone graft substitution and are used in combination with a variety of bioagents [1]. Regenerative medicine benefits from biocompatible scaffolds on which stem cells can grow and differentiate, either under preliminary ex vivo conditions for further grafting into the injured organ or as direct in vivo implants. Tissue engineering scaffolds offer microstructured $2 \mathrm{D}$ or $3 \mathrm{D}$ surfaces for cell attachment, differentiation, and proliferation [2]. In addition, scaffolds provide biomechanical properties that are suitable for supporting novel tissue structures and with no toxic effects. However, studies have demonstrated the need for stimulators of cell attachment, as many polymeric materials used for scaffold fabrication inhibit cell attachment and proliferation. In order to solve this 
problem, growth factors and cell ligands are incorporated as biologically active molecules to facilitate cell attachment and expansion.

Current and future applications of magnetic nanoparticles in biology and medicine have been largely dependent on their nanometer-size particles (3-10 $\mathrm{nm}$ in diameter) which exhibit novel magnetic, chemical, and biomedical properties [3]. Maghemite $\left(\gamma-\mathrm{Fe}_{2} \mathrm{O}_{3}\right)$, magnetite $\left(\mathrm{Fe}_{3} \mathrm{O}_{4}\right)$, and FeII/FeIII oxides are technologically important compounds widely used for the production of magnetic materials and catalysts. As a confirmation of cytocompatibility of magnetic material in tissue engineering, an emerging tissue engineering strategy, magnetic force-based tissue engineering (Mag-TE), employs cells that have been magnetically labelled with magnetite cationic liposomes (MCLs). Such MCL-labelled cells can be manipulated and organised by magnetic force, and their functionality is maintained. The use of magnetic material to manipulate cells has been tested in many cell lines including mesenchymal stem cells, cardiomyocytes [4], human umbilical vein endothelial cells [5], retinal pigment epithelial cells [6], and keratinocytes [7].

In this study, polymeric $\mathrm{P}(3 \mathrm{HB})$ based magnetic iron oxide (mainly magnetite) composite scaffolds were successfully developed using a simple and inexpensive compression moulding/particulate leaching technique. The two different types of magnetic composite scaffolds produced included $\mathrm{P}(3 \mathrm{HB}) /$ magnetic nanoparticles, $\mathrm{P}(3 \mathrm{HB}) / \mathrm{MNP}$, and $\mathrm{P}(3 \mathrm{HB}) /$ ferrofluid, $\mathrm{P}(3 \mathrm{HB}) / \mathrm{FF}$. The developed magnetic scaffolds were characterized for their magnetic properties as well as the effects of addition of magnetic materials (particles and fluid) on the thermomechanical properties of the composite scaffolds. FTIR was employed to study the crystallographic properties of the scaffolds. In vitro degradation study of the composite scaffolds was performed in simulated body fluid (SBF) to understand the effect of magnetic materials on the biodegradation of the composite scaffold. Magnetite was used for the manipulation of the nano- and microenvironments on $\mathrm{P}(3 \mathrm{HB})$ scaffolds in order to promote protein adsorption and subsequently stimulate cell proliferation. Cytocompatibility studies on the magnetic scaffolds were carried out using the human osteosarcoma MG-63 cell line and total protein production and cell proliferation were assessed. This study confirmed the promising potential application of the developed composites in bone tissue engineering and bone regeneration therapy.

\section{Experimental Procedures}

2.1. Bacterial Strain, Cells, and Culture Medium. Poly(3hydroxybutyrate) was produced following previously developed biotechnological methods [8]. The proliferation assays were performed using the HOS cell line, MG-63 grown in low glucose Dulbecco's Modified Eagle Medium (DMEM), supplemented with $10 \%$ fetal calf serum and $1 \%(\mathrm{w} / \mathrm{v})$ penicillin and $1 \%(\mathrm{w} / \mathrm{v})$ streptomycin solution.

2.2. Magnetic Nanoparticle Preparation. Magnetic nanocrystals of $\mathrm{Fe}_{3} \mathrm{O}_{4}$ were prepared by the classical coprecipitation method where a solution containing ferric and ferrous chlorides was introduced in an alkaline solution [9]. To the mixture of $2.0 \mathrm{~g} \mathrm{FeCl} \cdot 4 \mathrm{H}_{2} \mathrm{O}$ in $5 \mathrm{~mL} 2 \mathrm{M} \mathrm{HCl}$ and $5.4 \mathrm{~g} \mathrm{FeCl}_{3} \cdot 6 \mathrm{H}_{2} \mathrm{O}$ in $20 \mathrm{~mL} 2 \mathrm{M} \mathrm{HCl}, 50 \mathrm{~mL} 0.7 \mathrm{M} \mathrm{NH}_{3}$ was dropped under mixing. The magnetic particles were washed with water and acetone. These particles were used in the form of aggregates, particle size ca $100 \mathrm{~nm}$ ( $1 \mathrm{~mL}$ of centrifuged sample corresponded to $67 \mathrm{mg}$ of dry weight).

2.3. Preparation of Magnetic Fluid (Ferrofluid, FF) Stabilized in Chloroform. To the mixture of $2.0 \mathrm{~g} \mathrm{FeCl}_{2} \cdot 4 \mathrm{H}_{2} \mathrm{O}$ in $5 \mathrm{~mL}$ $2 \mathrm{M} \mathrm{HCl}$ and $5.4 \mathrm{~g} \mathrm{FeCl}_{3} \cdot 6 \mathrm{H}_{2} \mathrm{O}$ in $20 \mathrm{~mL} 2 \mathrm{M} \mathrm{HCl}, 50 \mathrm{~mL}$ $0.7 \mathrm{M} \mathrm{NH}_{3}$ was dropped under mixing. Then concentrated (25\%) $\mathrm{NH}_{3}$ was added to the total volume $66 \mathrm{~mL}$ and $\mathrm{pH}$ ca 10 . After that $1.3 \mathrm{~mL}$ oleic acid was added and thoroughly mixed for $1 \mathrm{~h}$. Then the mixture was heated in water bath to $95^{\circ} \mathrm{C}$ with temperature increasing $2^{\circ} \mathrm{C} / \mathrm{s}$ (45-60 min). After cooling down $15 \% \mathrm{HNO}_{3}$ was added to $\mathrm{pH}$ 5. The suspension was then washed with water and subsequently with acetone (both four times). Magnetite in acetone was heated for $1.5 \mathrm{~h}$ under mixing in water bath at $35-50^{\circ} \mathrm{C}$ until all acetone was evaporated. Then chloroform was added in small portions until ferrofluid was formed. To remove solid particles the ferrofluid was repeatedly centrifuged (90 min, $9500 \mathrm{rpm}$ ), under the same conditions, up to 4-6 days. The relative magnetic fluid concentration $(25 \mathrm{mg} / \mathrm{mL})$ was determined by a colorimetric method $\left(\mathrm{Fe}_{3} \mathrm{O}_{4}\right.$ used as standard); $\mathrm{pH}$ was ca $7.0[10]$.

2.4. Nanocomposite Film Preparation. $1 \mathrm{~g}$ of $\mathrm{P}(3 \mathrm{HB})$ was dissolved in $10 \mathrm{~mL}$ of $\mathrm{CHCl}_{3}$ at room temperature and stirred for $24 \mathrm{~h}$. The desired amount of magnetic nanoparticles/ferrofluid in $\mathrm{CHCl}_{3}$ was added to the $\mathrm{P}(3 \mathrm{HB})$ solution to give a final concentration of 14,27 , and $54 \mathrm{mg} / \mathrm{mL}$ of either MNP or FF and the mixture was homogenized for 2 min using a homogenizer (Ultra-Turrax T25 basic, Ika-Werke). The suspension was then degassed three times and poured into a glass Petri-dish, where the films were obtained by solvent evaporation at room temperature. Hence, nanocomposite films containing 14,27 , and $54 \mathrm{mg} / \mathrm{g}$ of $\mathrm{P}(3 \mathrm{HB})$ were prepared.

2.5. Scanning Electron Microscopy (SEM). Scanning electron microscopy, JEOL 5610LV instrument (JEOL, USA) and an ESEM FEI Quanta 200F, was used to examine the microstructure of the test materials. The samples were placed on $8 \mathrm{~mm}$ diameter aluminium stubs using a sticky tag to hold them. A gold sputtering device (EMITECH-K550) was used to coat the samples, operating at a pressure of $7 \times 10^{-2}$ bar and deposition current of $20 \mathrm{~mA}$ for $2 \mathrm{~min}$. Images were taken at various acceleration voltages (maximum of $20 \mathrm{kV}$ ) to avoid beam damage on the polymer.

2.6. SQUID Analysis. A superconducting quantum interference device magnetometer (SQUID, MPMS XL-7 type, Quantum Design, USA) was used for measurement of magnetization of the solid samples. The hysteresis loops of all studied samples were collected at a temperature of $300 \mathrm{~K}$ under an external magnetic field ranging from $-1 \mathrm{~T}$ to $+1 \mathrm{~T}$ 
(i.e., $10 \mathrm{kOe}$ ). For measurement, a small sample (few $\mathrm{mm}^{3}$ ) of the scaffold was mounted onto the sample holder using a Teflon tape.

2.7. Dynamic Mechanical Analysis (DMA). DMA experiments were carried out in tensile mode using a PerkinElmer Dynamic Mechanical Analyser (DMA 7e, PerkinElmer Instruments, USA) at room temperature. Tensile strength tests were conducted on flat specimens (width: $1.4 \mathrm{~mm}$, length: $7-8 \mathrm{~mm}$, and thickness: $\approx 100-120 \mu \mathrm{m}$ ) cut out from the solvent cast films. To remove any trace of solvent, samples were first heated from room temperature to $100^{\circ} \mathrm{C}$ at $10^{\circ} \mathrm{C} / \mathrm{min}, 1 \mathrm{~Hz}$ frequency, and $0.01 \%$ of strain, and this temperature was kept for $10 \mathrm{~min}$. Then dynamic cooling scans were conducted from 100 to $30^{\circ} \mathrm{C}$ at $2^{\circ} \mathrm{C} / \mathrm{min}, 1 \mathrm{~Hz}$, and $0.1 \%$ of strain. During the DMA experiment, the static load was kept at $1 \mathrm{mN}$ and it was increased to $6000 \mathrm{mN}$ at a rate of $200 \mathrm{mN} \mathrm{min}^{-1}$. Four repeat specimens were tested for each sample and the average value was used.

2.8. Infrared Spectroscopy (FTIR). Infrared spectra of dried test samples were recorded using a FTS 6000 spectrometer (Portmann Instruments AG, Biel-Benken, Switzerland). For each sample, the diamond crystal of an attenuated total reflectance (ATR) accessory was brought into contact with the area to be analysed. The contact area was about $2 \mathrm{~mm}^{2}$, and a torque of $10 \mathrm{c} \mathrm{Nm}$ was used to ensure the same pressure on each sample. All spectra were recorded between 4000 and $400 \mathrm{~cm}^{-1}$, with a resolution of $4 \mathrm{~cm}^{-1}$ and 32 scans.

2.9. Contact Angle Study. In order to evaluate the wettability of the test materials, static contact angle measurements were carried out on each of the samples. The experiment was carried out on a KSV-Cam 200 optical contact angle meter (KSV Instruments Ltd., Finland). An equal volume of water $(20 \mu \mathrm{L})$ was placed on every sample by means of a gas tight microsyringe forming a meniscus. Photos (frame intervals: $1 \mathrm{~s}$, number of frames: 100) were taken to record the shape of the meniscus. The water contact angles on the specimens were measured by analyzing the recorded drop images (four repeats for each sample) using the Windows based KSV-Cam software.

2.10. Protein Adsorption Study. Protein adsorption assay was carried out on 2D (films) using fetal bovine serum (FBS). All measurements were carried out in triplicate per sample. The samples were immersed with $200 \mu \mathrm{L}$ of undiluted FBS in a $1.5 \mathrm{~mL}$ Eppendorf and incubated at $37^{\circ} \mathrm{C}$ for $24 \mathrm{~h}$. The serum was then removed from the samples and the samples were washed three times with phosphate buffer saline (PBS). The proteins adsorbed on the samples were collected by incubating the samples with $1 \mathrm{~mL}$ of $2 \%$ sodium dodecyl sulphate (SDS) in PBS for $24 \mathrm{~h}$ at room temperature and under vigorous shaking. This was done to ensure the adsorbed proteins were dissolved in the PBS (with SDS). Amount of total protein adsorbed was measured using a commercial protein quantification kit (Qubit ${ }^{\mathrm{TM}}$ Protein Assay Kits). Fluorescence was measured at $485 / 590 \mathrm{~nm}$ against a calibration curve using bovine serum albumin, BSA (provided in the kit).

2.11. Change in $p H$ of Simulated Body Fluid, SBF, after Immersion of Samples. A total of nine samples from each group of the test materials were immersed in SBF for 1, 2, 3 , and 4 weeks and $20 \mathrm{~mL} \mathrm{SBF}$ was used for each sample. $\mathrm{SBF}$ was chosen because it has similar ionic concentration to human blood plasma [11]. The $\mathrm{pH}$-values of SBF were monitored every week by an electrolyte-type $\mathrm{pH}$ meter (PHS2C, JingkeLeici Co., Shanghai, China). The values presented were the mean values of triplicate measurements.

2.12. Cytocompatibility Studies. In vitro cell culture studies were performed using MG-63 osteoblast, a human osteosarcoma cell line. Cells were cultured in Dulbecco's Modified Eagles Medium (DMEM) from PAA, Germany, supplemented with $10 \%(\mathrm{v} / \mathrm{v})$ fetal calf serum and $1 \%(\mathrm{v} / \mathrm{v})$ penicillin and streptomycin solution and incubated at $37^{\circ} \mathrm{C}$ in a humidified atmosphere ( $5 \% \mathrm{CO}_{2}$ in $95 \%$ air) prior to its use. The samples were UV-sterilized for $30 \mathrm{~min}$ and passivated in DMEM culture medium for $12 \mathrm{~h}$, prior to seeding the cells. The samples were placed in a polystyrene 24 well flat bottomed tissue culture plate with the film samples placed in the centre of the well. Standard tissue culture plastic was used as the control surface. The specified amounts of cells (20,000 cells/samples) were seeded using $50 \mu \mathrm{L}$ of DMEM medium for initial attachment of the MG-63 on the sample surface. The plates were incubated in a humidified environment $\left(37^{\circ} \mathrm{C}, 5 \% \mathrm{CO}_{2}\right)$ for a period of up to $2 \mathrm{~h}$ and then samples transferred to a new well-plate and replaced with $1 \mathrm{~mL}$ of DMEM medium. The cells were then allowed to grow on the films $(n=3)$ for a period of up to 7 days with the medium changed every second day. At specific time intervals the cell proliferation measurements were carried out using the Alamar blue (AbD Serotec, UK) assay and the fluorescence of the samples was measured at $560 \mathrm{~nm}\left(A_{560}\right)$ and $590 \mathrm{~nm}\left(A_{590}\right)$. Films were also examined under SEM JEOL 5610LV instrument (JEOL, USA) after day 7 to assess the cell spreading and attachment.

\section{Results}

3.1. Microstructural Analysis of Neat $P(3 H B), P(3 H B) / M N P$, and $P(3 H B) / F F$ Composites. Microstructural analysis of the neat $\mathrm{P}(3 \mathrm{HB})$ and the composite test materials $(\mathrm{P}(3 \mathrm{HB}) / \mathrm{MNP}$ and $\mathrm{P}(3 \mathrm{HB}) / \mathrm{FF}$ ) were carried out using SEM. Film samples containing $54 \mathrm{mg} / \mathrm{mL}$ of either MNPs or FF were shown to illustrate the differences in the surface morphology of the tested samples.

The surface morphology of the films produced by solvent casting, as observed from the SEM imaging, is shown in Figure 1. The SEM image revealed micro/nanosurfaces on the test materials. Nano/microscale crystals and sparsely distributed aggregates of nanoscale crystals were observed on the surface of the $\mathrm{P}(3 \mathrm{HB}) / \mathrm{MNP}$ composite. These nanoscale crystals were more visible at a higher magnification $(\times 500)$ image. As expected, the surfaces of the composite materials were slightly rougher than that of neat $\mathrm{P}(3 \mathrm{HB})$. 


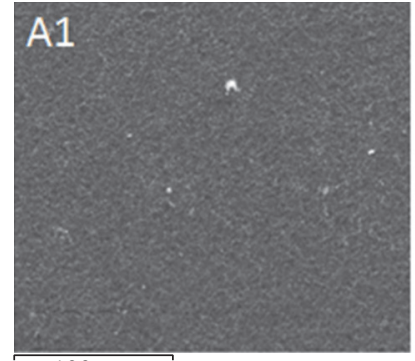

$100 \mu \mathrm{m}$

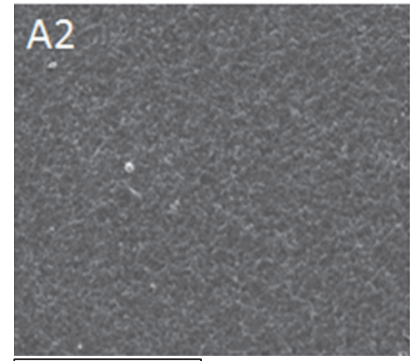

$60 \mu \mathrm{m}$

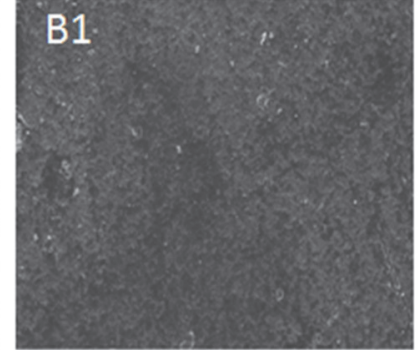

$300 \mu \mathrm{m}$

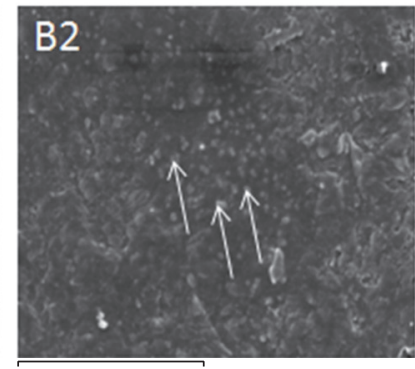

$40 \mu \mathrm{m}$

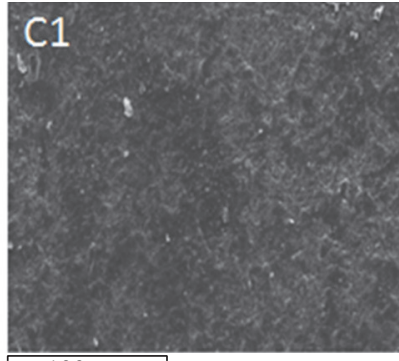

$100 \mu \mathrm{m}$

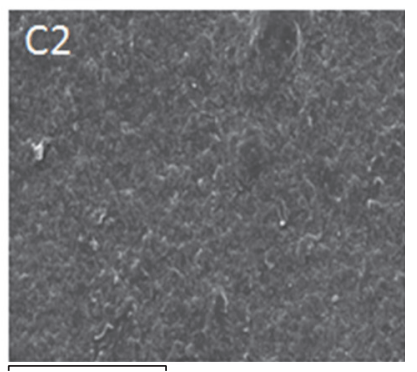

$100 \mu \mathrm{m}$

Figure 1: SEM image of (A1) neat $\mathrm{P}(3 \mathrm{HB})$; (B1) $\mathrm{P}(3 \mathrm{HB}) / \mathrm{MNP})(54 \mathrm{mg} / \mathrm{mL})$; (C1) $\mathrm{P}(3 \mathrm{HB}) / \mathrm{FF}(54 \mathrm{mg} / \mathrm{mL})$ at lower magnification $(\times 150)$ and higher magnification; (A2) neat (P(3HB); (B2) P(3HB)/MNP (54 mg/mL); (C2) P(3HB)/FF (54 mg/mL). The arrows show the uniformly dispersed magnetic particles.

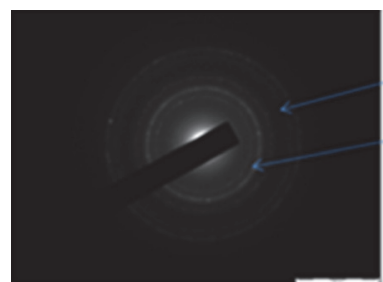

(a)

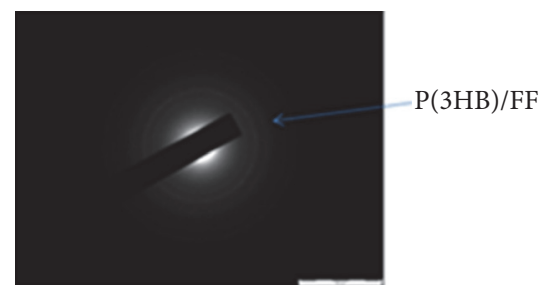

(b)

Figure 2: Electron diffraction patterns of (a) $\mathrm{P}(3 \mathrm{HB}) / \mathrm{MNP}$ and (b) $\mathrm{P}(3 \mathrm{HB}) / \mathrm{FF}$ composite films.

3.2. Morphology and Structure of Magnetic Materials in the Composite Scaffolds. Electron diffraction patterns of the test materials are presented in Figure 2. The electron diffraction patterns show a randomly oriented $\mathrm{Fe}_{3} \mathrm{O}_{4}$ in the $\mathrm{P}(3 \mathrm{HB}) / \mathrm{MNP}$ and $\mathrm{P}(3 \mathrm{HB}) / \mathrm{FF}$ composite scaffolds.

\subsection{Magnetic Properties of $P(3 H B) / M N P$ and $P(3 H B) / F F$} Composite Material. Magnetic properties of the biodegradable nanocomposite scaffolds were investigated using superconducting quantum interference device (SQUID) as described in Section 2.6. For each sample the magnetization at $300 \mathrm{~K}$ was measured over a range of applied fields between $-10,000$ and $+10,000$ Oe. Figure $3(\mathrm{a})$ shows the neat $\mathrm{P}(3 \mathrm{HB})$ having a very low maximum magnetization $M_{\max +}$ at $1 \mathrm{~T}$ $(0.004 \mathrm{emu} / \mathrm{g})$ while Figure 3 (b) shows that, near \pm 1 , the magnetization reached a saturation value $(0.004,0.6182$, and $0.8707 \mathrm{emu} / \mathrm{g}$ ) roughly proportional to the MNP content $(14,27$, and $54 \mathrm{mg}$ ) in the scaffolds. Figure 4(a) features the hysteresis loops of the composite scaffold produced by addition of ferrofluid (FF) (54 mg, ca $=10-15 \mathrm{~nm}$ ) while Figure 4(b) features the hysteresis loops of the scaffold produced by the incorporation of magnetic nanoparticles (MNP) $(54 \mathrm{mg} / \mathrm{mL})$. Figures $4(\mathrm{a})$ and $4(\mathrm{~b})$ show that the hysteresis loops of $\mathrm{P}(3 \mathrm{HB}) / \mathrm{FF}$ and $\mathrm{P}(3 \mathrm{HB}) / \mathrm{MNP}$ composites almost saturate at \pm 1 Tesla without coercivity or remnant magnetization (i.e., ascending and descending curves are almost the same).

3.4. Mechanical and Thermomechanical Properties of $P(3 \mathrm{HB}) /$ $M N P$ and $P(3 H B) / F F$ Composite. Dynamic mechanical analysis, DMA, has been demonstrated to be useful in evaluating the viscoelastic properties of polymers $[12,13]$. For polymeric materials, the following equations hold [14]:

$$
\begin{aligned}
E & =\frac{\sigma}{\varepsilon}=E^{\prime}+E^{\prime \prime}, \\
\tan \delta & =\frac{E^{\prime}}{E^{\prime \prime}},
\end{aligned}
$$

where $E$ is the dynamic modulus, $E^{\prime}$ is termed storage modulus, $E^{\prime \prime}$ is the loss modulus, $\sigma$ (sigma) is stress, $\varepsilon$ (epsilon) is percentage change in strain, and $\tan \delta$ (tan delta) is the ratio 


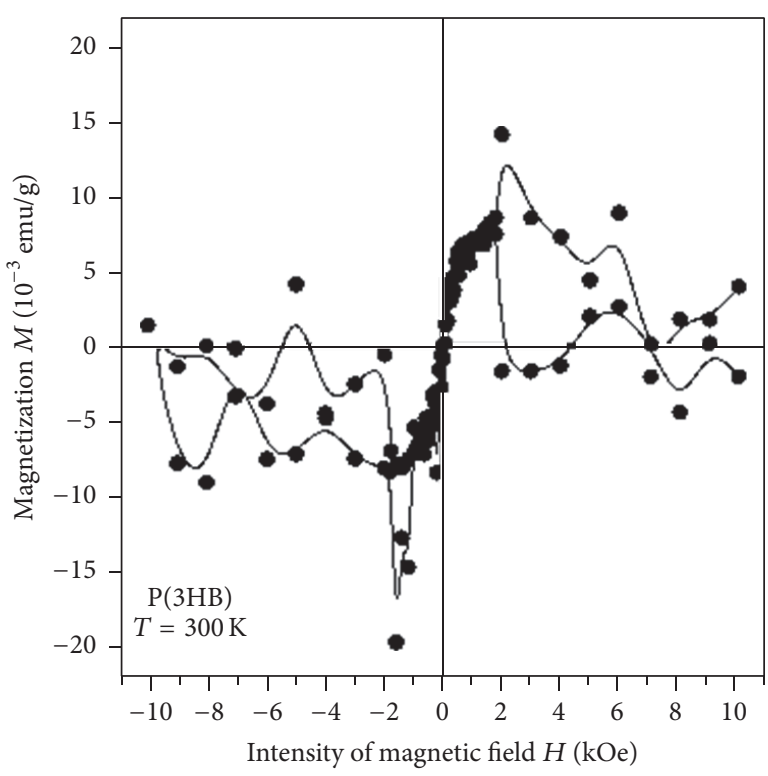

(a)

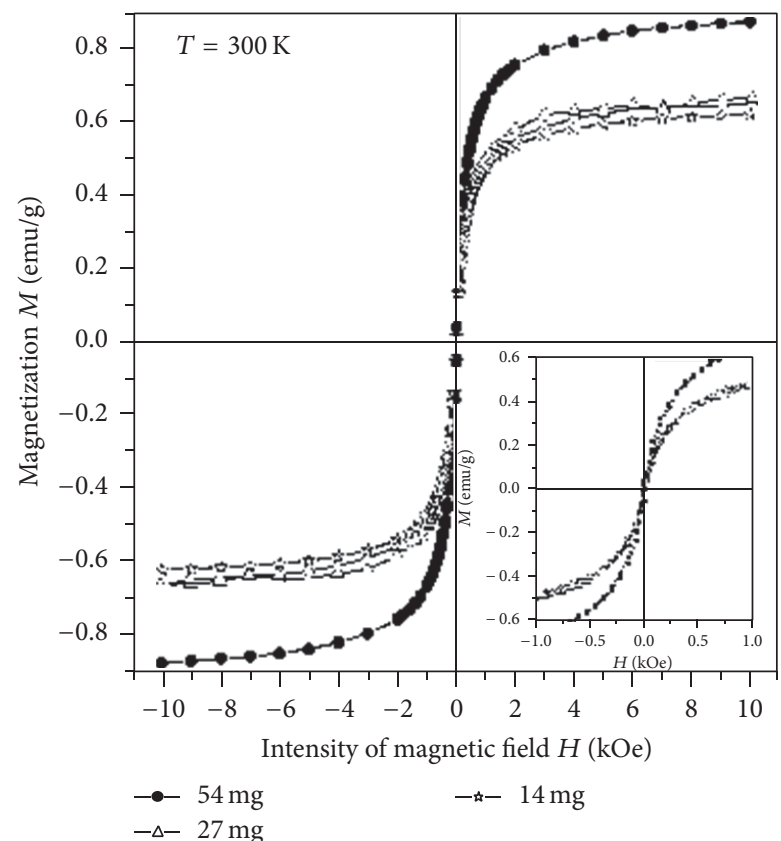

(b)

FIGURE 3: Hysteresis loops of SQUID measurement of (a) neat $\mathrm{P}(3 \mathrm{HB})$ and (b) $\mathrm{P}(3 \mathrm{HB}) / \mathrm{MNP}$ composite film containing different amounts of $\operatorname{MNP}(14,27$, and $54 \mathrm{mg})$.

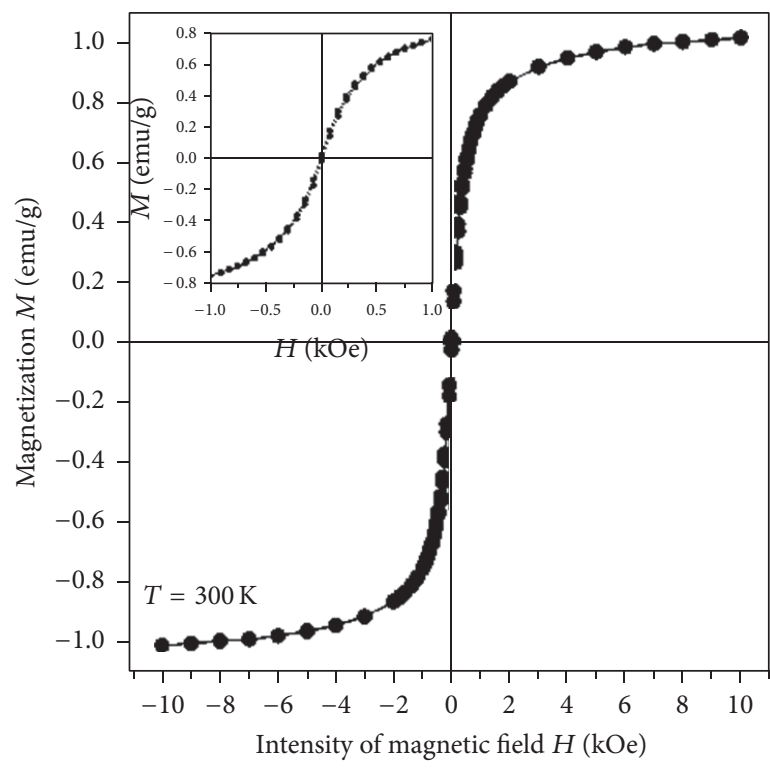

(a)

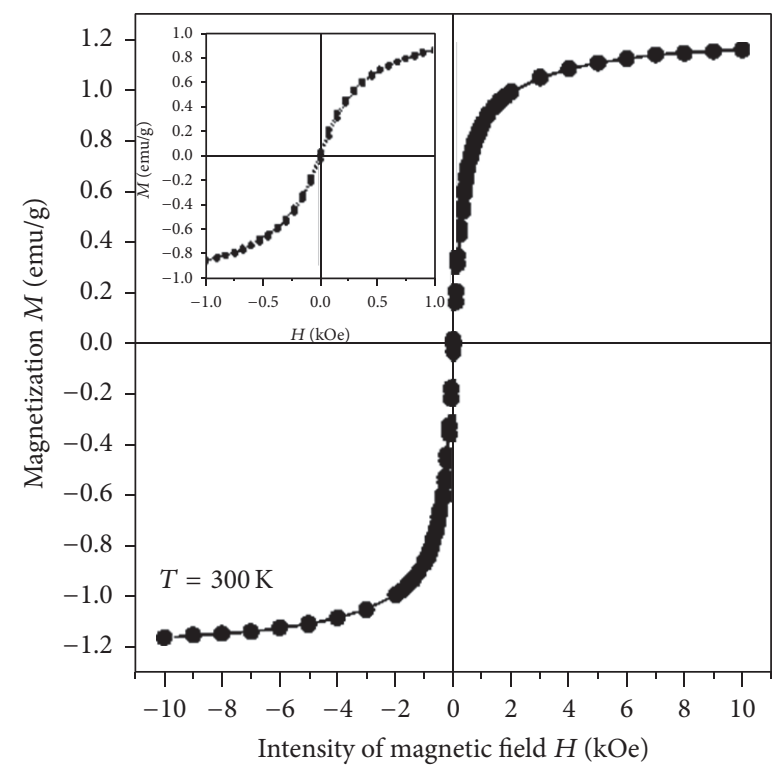

(b)

FIGURE 4: Hysteresis loops of SQUID measurement of (a) $\mathrm{P}(3 \mathrm{HB}) / \mathrm{FF}$ composite film $(54 \mathrm{mg} / \mathrm{mL}$, average particle size, ca $=10-15 \mathrm{~nm})$ and $\mathrm{P}(3 \mathrm{HB}) / \mathrm{MNP}$ composite $(54 \mathrm{mg}, \mathrm{ca}=100 \mathrm{~nm})$.

of the energy dissipated per cycle to the energy stored during the cycle.

Table 1 shows Young's modulus of the $\mathrm{P}(3 \mathrm{HB}) / \mathrm{MNP}$ and $\mathrm{P}(3 \mathrm{HB}) / \mathrm{FF}$ composites which were significantly influenced by the incorporation of magnetic oxides either as nanoparticles or as ferrofluid. Young's modulus of the neat $\mathrm{P}(3 \mathrm{HB})$ measured was $0.22 \pm 0.04 \mathrm{GPa}$. This value increased to 0.83 \pm 0.2 and $0.94 \pm 0.4 \mathrm{GPa}$ on addition of $14 \mathrm{mg}$ of MNP and $14 \mathrm{mg}$ of ferrofluid, respectively, to $1 \mathrm{~g}$ of the $\mathrm{P}(3 \mathrm{HB})$ matrix to form composites (Figure 5). The result of the static test thus showed that there was a $277 \%$ and $327 \%$ increase in Young's modulus of the composite due to the incorporation of $14 \mathrm{mg}$ of either MNP or ferrofluid, respectively. Statistically significant differences $(p<0.05)$ were observed between 
TABLE 1: Mean and standard deviation of storage modulus $\left(E^{\prime}\right)$ and loss modulus $\left(E^{\prime \prime}\right)$ for neat $\mathrm{P}(3 \mathrm{HB}), \mathrm{P}(3 \mathrm{HB}) / \mathrm{MNP}$, and $\mathrm{P}(3 \mathrm{HB}) / \mathrm{FF}$ composites at different temperatures.

\begin{tabular}{|c|c|c|c|c|c|}
\hline \multirow{2}{*}{ Measurement } & \multirow{2}{*}{ Material } & \multicolumn{4}{|c|}{ Temperature $\left({ }^{\circ} \mathrm{C}\right)$} \\
\hline & & -20 & 0 & 20 & 50 \\
\hline \multirow{3}{*}{ Storage modulus (GPa) } & Neat $\mathrm{P}(3 \mathrm{HB})$ & $0.98 \pm 0.7$ & $0.86 \pm 0.4$ & $0.74 \pm 0.6$ & $0.61 \pm 0.4$ \\
\hline & $\mathrm{P}(3 \mathrm{HB}) / \mathrm{MNP}$ & $2.77 \pm 0.7$ & $2.28 \pm 0.5$ & $1.87 \pm 0.30$ & $1.36 \pm 0.5$ \\
\hline & $\mathrm{P}(3 \mathrm{HB}) / \mathrm{FF}$ & $1.97 \pm 0.5$ & $1.59 \pm 0.1$ & $1.30 \pm 0.3$ & $0.95 \pm 0.1$ \\
\hline \multirow{3}{*}{ Loss modulus (GPa) } & Neat $\mathrm{P}(3 \mathrm{HB})$ & $0.09 \pm 0.02$ & $0.08 \pm 0.02$ & $0.06 \pm 0.01$ & $0.06 \pm 0.04$ \\
\hline & $\mathrm{P}(3 \mathrm{HB}) / \mathrm{MNP}$ & $0.76 \pm 0.3$ & $0.68 \pm 0.1$ & $0.06 \pm 0.01$ & $0.05 \pm 0.01$ \\
\hline & $\mathrm{P}(3 \mathrm{HB}) / \mathrm{FF}$ & $0.84 \pm 0.2$ & $0.67 \pm 0.1$ & $0.49 \pm 0.1$ & $0.34 \pm 0.3$ \\
\hline \multirow{3}{*}{$\tan \delta$} & Neat $\mathrm{P}(3 \mathrm{HB})$ & $0.09 \pm 0.02$ & $0.09 \pm 0.04$ & $0.08 \pm 0.03$ & $0.10 \pm 0.07$ \\
\hline & $\mathrm{P}(3 \mathrm{HB}) / \mathrm{MNP}$ & $0.27 \pm 0.04$ & $0.29 \pm 0.09$ & $0.26 \pm 0.02$ & $0.37 \pm 0.02$ \\
\hline & $\mathrm{P}(3 \mathrm{HB}) / \mathrm{FF}$ & $0.43 \pm 0.02$ & $0.42 \pm 0.01$ & $0.38 \pm 0.03$ & $0.36 \pm 0.01$ \\
\hline
\end{tabular}

$\operatorname{MNP}(54 \mathrm{mg} / \mathrm{mL}), \mathrm{FF}(54 \mathrm{mg} / \mathrm{mL})$, and $\tan \delta(\tan$ delta) $(n=3$, error $= \pm \mathrm{SD})$.

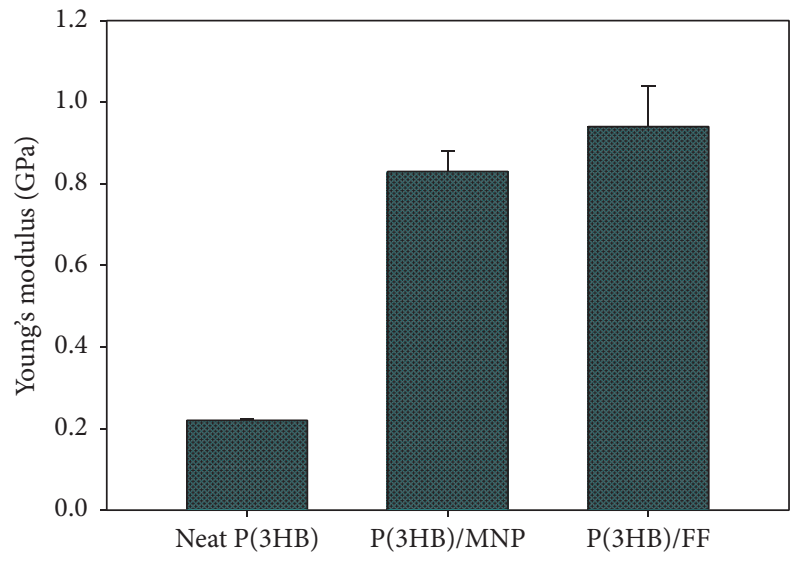

FIgURE 5: Young's modulus (E) measurement for neat $\mathrm{P}(3 \mathrm{HB})$, $\mathrm{P}(3 \mathrm{HB}) / \mathrm{MNP}$, and $\mathrm{P}(3 \mathrm{HB}) / \mathrm{FF}$ composite containing $14 \mathrm{mg}$ of either $\mathrm{MNP}$ or ferrofluid solution in $1 \mathrm{~g}$ of $\mathrm{P}(3 \mathrm{HB})$. (Error bars $= \pm \mathrm{SD}$.)

the elastic moduli of the $\mathrm{P}(3 \mathrm{HB}) / \mathrm{MNP}$ and $\mathrm{P}(3 \mathrm{HB}) / \mathrm{FF}$ composites.

Figures 6(a) and 6(b) highlight the result of the dynamic moduli measured on both the neat $\mathrm{P}(3 \mathrm{HB})$ and $\mathrm{P}(3 \mathrm{HB}) / \mathrm{MNP}$ and $\mathrm{P}(3 \mathrm{HB}) / \mathrm{FF}$ composites. The dynamic storage and loss modulus were obtained in the temperature range of $-20^{\circ} \mathrm{C}$ and $130^{\circ} \mathrm{C}$ and a typical profile of the data obtained is shown in Figures 6(a) and 6(b). A detailed set of data with standard deviations on the three sets of analyses performed is shown in Table 1. The result shows that the storage modulus increased due to the incorporation of either magnetic nanoparticles or ferrofluid to the polymeric matrix. However, the storage modulus of the $\mathrm{P}(3 \mathrm{HB}) / \mathrm{MNP}$ composite was found to be greater than the storage modulus measured for both neat $\mathrm{P}(3 \mathrm{HB})$ and $\mathrm{P}(3 \mathrm{HB}) / \mathrm{FF}$ composite. At $-20^{\circ} \mathrm{C}$, the storage modulus was found to be $0.97 \pm 0.7,2.77 \pm 0.7$, and $1.97 \pm$ $0.5 \mathrm{GPa}$ for the neat $\mathrm{P}(3 \mathrm{HB}), \mathrm{P}(3 \mathrm{HB}) / \mathrm{MNP}$, and $\mathrm{P}(3 \mathrm{HB}) / \mathrm{FF}$ composites, respectively. Moreover, both the storage modulus and loss modulus were found to decrease with increase in temperature. Apart from dynamic storage and loss modulus, $\tan \delta$ (which is the ratio of the energy dissipated per cycle to the energy stored during the cycle) was used to quantify the internal friction existing in the material. The test performed clearly revealed that $\tan \delta$ increased with the addition of either magnetic nanoparticles or ferrofluid to the polymeric material. Also, $\tan \delta$ decreased with increase in temperature in both $\mathrm{P}(3 \mathrm{HB}) / \mathrm{MNP}$ and $\mathrm{P}(3 \mathrm{HB}) / \mathrm{FF}$ composite materials but increased with increase in temperature above $20^{\circ} \mathrm{C}$ for neat $\mathrm{P}(3 \mathrm{HB})$ (Table 1$)$.

3.5. Fourier Transform-Infrared, FTIR, Analysis. Fourier transform infrared (FTIR) spectroscopy was used to identify functional groups and obtain structural information of neat $\mathrm{P}(3 \mathrm{HB})$ and the composites. In any miscible composites, polymers containing the carbonyl group usually are involved in some interaction such as hydrogen bonds; hence, a shift of the adsorption wavelength corresponding to the $\mathrm{C}=\mathrm{O}$ group is usually observed.

The FTIR spectra of $\mathrm{P}(3 \mathrm{HB}), \mathrm{P}(3 \mathrm{HB}) / \mathrm{MNP}$, and $\mathrm{P}(3 \mathrm{HB}) /$ $\mathrm{FF}$ composites are shown in Figure 7 . The strong and sharp transmittance band at $1720 \mathrm{~cm}^{-1}$ can be assigned to the $\mathrm{C}=\mathrm{O}$ stretching mode in both the neat $\mathrm{P}(3 \mathrm{HB})$ and the composite specimens. The peaks at $1275 \mathrm{~cm}^{-1}$ and $1226 \mathrm{~cm}^{-1}$ can be assigned to the $\mathrm{C}-\mathrm{O}-\mathrm{C}$ stretching modes in the composites. The peak at $1180 \mathrm{~cm}^{-1}$ is attributed to the $\mathrm{C}-\mathrm{O}-\mathrm{C}$ stretching band corresponding to the amorphous state [15]. Generally, the FTIR spectra of the composite specimens show modified bands in shape and intensity when compared to those characteristics of neat $\mathrm{P}(3 \mathrm{HB})$. Most of the $\mathrm{P}(3 \mathrm{HB})$ bands that are sensitive to the crystallinity of the sample became sharp and increased in intensity with the addition of either magnetic nanoparticles or ferrofluid. Furthermore, the intensity of these bands increased more with the addition of ferrofluid than on addition of MNP. For instance, the intensity of the peaks at positions 2978, 1720, 1378, 1275, 1129, 1050,909 , and $592 \mathrm{~cm}^{-1}$ increased in the order $\mathrm{P}(3 \mathrm{HB})<$ $\mathrm{P}(3 \mathrm{HB}) / \mathrm{MNP}<\mathrm{P}(3 \mathrm{HB}) / \mathrm{FF}$. Also, conspicuous was the shift in bands with the addition of the fillers. The $591 \mathrm{~cm}^{-1}$ peak in the neat $\mathrm{P}(3 \mathrm{HB})$ spectrum shifted to $592 \mathrm{~cm}^{-1}$ in $\mathrm{P}(3 \mathrm{HB}) / \mathrm{FF}$ and $593 \mathrm{~cm}^{-1}$ in $\mathrm{P}(3 \mathrm{HB}) / \mathrm{MNP}$ while the band at position 


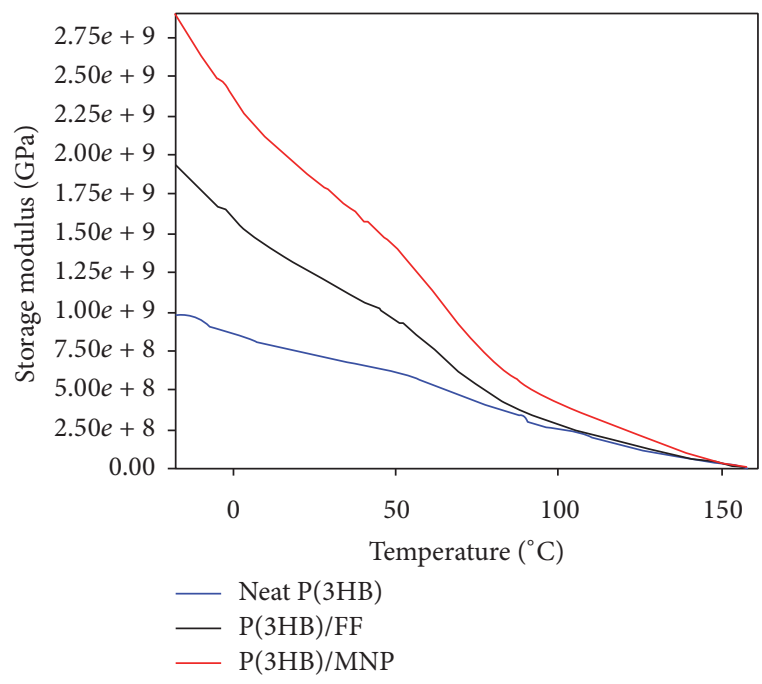

(a)

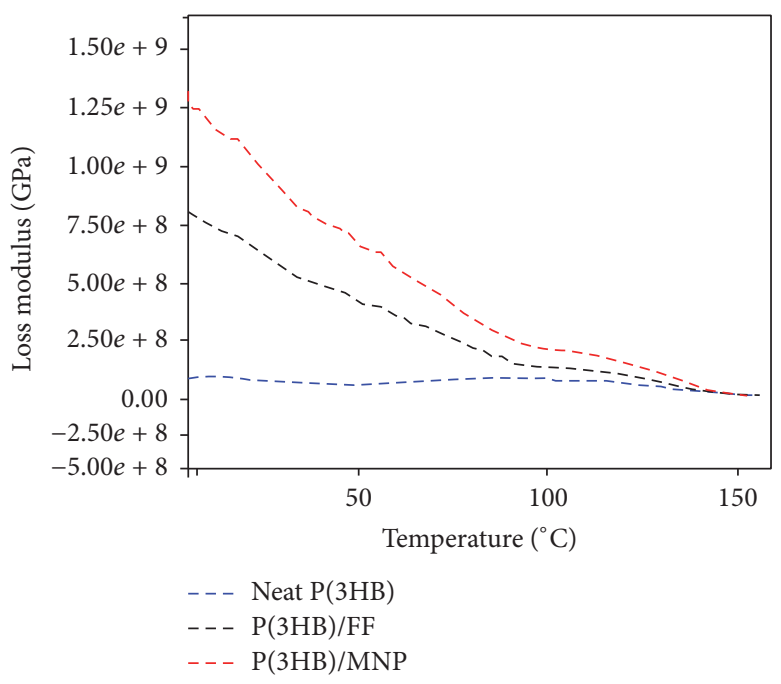

(b)

Figure 6: Typical plot of (a) storage modulus (solid lines) and (b) loss modulus (dotted lines) of neat $\mathrm{P}(3 \mathrm{HB}), \mathrm{P}(3 \mathrm{HB}) / \mathrm{FF}$, and $\mathrm{P}(3 \mathrm{HB}) / \mathrm{MNP}$ composites.

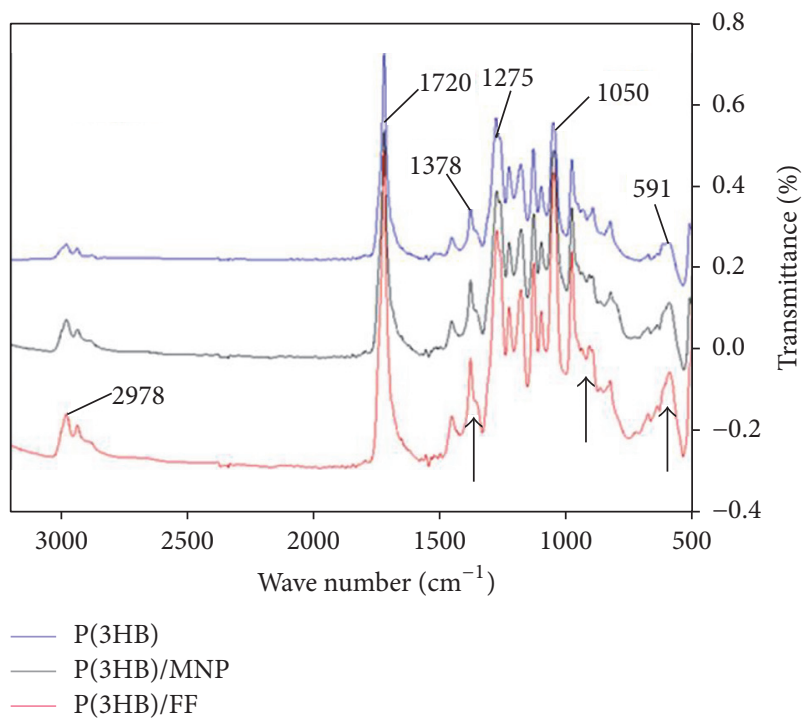

Figure 7: FTIR spectra of neat $\mathrm{P}(3 \mathrm{HB})$ (blue line), $\mathrm{P}(3 \mathrm{HB}) / \mathrm{MNP}$ (54 mg/mL) (black line), and $\mathrm{P}(3 \mathrm{HB}) / \mathrm{FF}(54 \mathrm{mg} / \mathrm{mL})$ (red line).

$1451 \mathrm{~cm}^{-1}$ in the neat $\mathrm{P}(3 \mathrm{HB})$ shifted to $1454 \mathrm{~cm}^{-1}$ on addition of either magnetic nanoparticles or ferrofluid. Besides, additional bands were also found at position $511 \mathrm{~cm}^{-1}$ in the $\mathrm{P}(3 \mathrm{HB}) / \mathrm{MNP}$ composite and $1556 \mathrm{~cm}^{-1}$ in both composite specimens $(\mathrm{P}(3 \mathrm{HB}) / \mathrm{MNP}$ and $\mathrm{P}(3 \mathrm{HB}) / \mathrm{FF})$, which were due to the presence of the fillers.

3.6. Hydrophilicity Determination. The water contact angle of the composites differed significantly from that of the neat $\mathrm{P}(3 \mathrm{HB})$ as seen in Figure 8. While the water contact angle measured on the neat $\mathrm{P}(3 \mathrm{HB})$ specimen was $68.1 \pm 7$, those measured on the $\mathrm{P}(3 \mathrm{HB}) / \mathrm{MNP}$ and $\mathrm{P}(3 \mathrm{HB}) / \mathrm{FF}$ were $59.7 \pm$ 4.1 and $63.2 \pm 6.4$, respectively. Hence, the hydrophilicity of

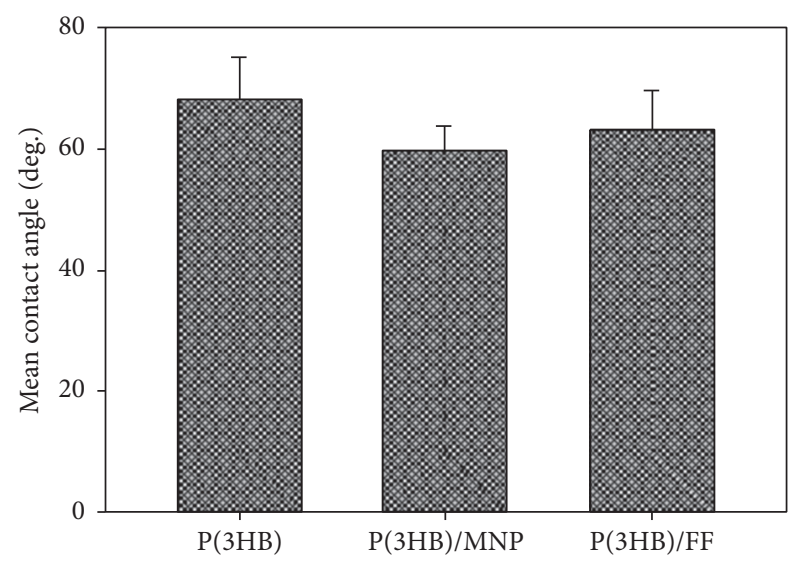

FIgure 8: Water contact angles for neat $\mathrm{P}(3 \mathrm{HB}), \mathrm{P}(3 \mathrm{HB}) / \mathrm{MNP}$ $(54 \mathrm{mg} / \mathrm{mL})$, and $\mathrm{P}(3 \mathrm{HB}) / \mathrm{FF}(54 \mathrm{mg} / \mathrm{mL})$ composite films $(n=3$, error $= \pm \mathrm{SD}$ ).

the composite specimens increased by $12 \%$ and $7 \%$ on addition of magnetic nanoparticles and ferrofluid, respectively.

3.7. Total Protein Adsorption on the $P(3 H B) / M N P$ and $P(3 H B) / F F$ Composite Films. The total amount of protein adsorbed onto the composite disc in $\mu \mathrm{g} / \mathrm{cm}^{2}$ is shown in Figure 9. For all the specimens, the total amount of adsorbed protein increased significantly with the addition of either magnetic nanoparticles or ferrofluid. The total amount of protein absorbed by the $\mathrm{P}(3 \mathrm{HB}) / \mathrm{FF}$ and $\mathrm{P}(3 \mathrm{HB}) / \mathrm{MNP}$ composite scaffolds increased by 83 and $91 \%$, respectively, with respect to neat $\mathrm{P}(3 \mathrm{HB})$. A statistically significant difference $(p<0.05)$ was found between total proteins absorbed by either $\mathrm{P}(3 \mathrm{HB}) / \mathrm{MNP}$ or $\mathrm{P}(3 \mathrm{HB}) / \mathrm{FF}$ and the neat $\mathrm{P}(3 \mathrm{HB})$. However, among the composite specimens $(\mathrm{P}(3 \mathrm{HB}) / \mathrm{MNP}$ and $\mathrm{P}(3 \mathrm{HB}) / \mathrm{FF})$, the extent of protein adsorption did not differ significantly, though both composites followed the 


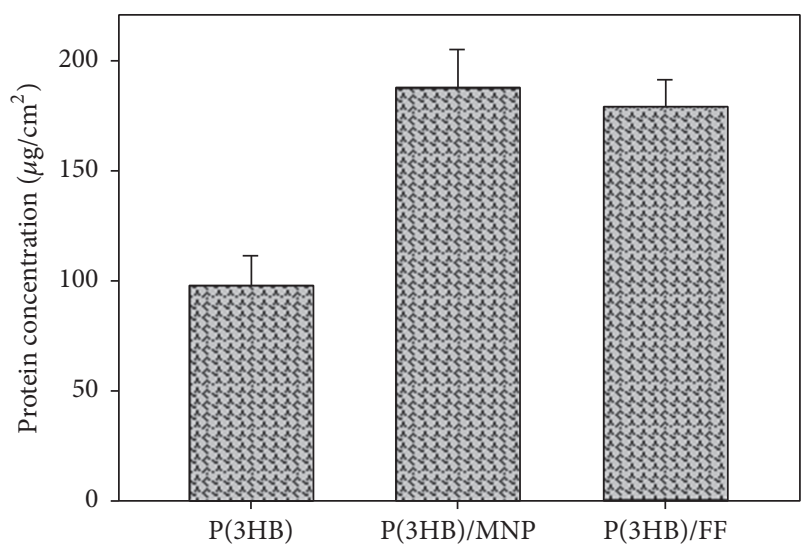

FIgURE 9: Total protein adsorption study on $\mathrm{P}(3 \mathrm{HB}) / \mathrm{MNP}$ $(54 \mathrm{mg} / \mathrm{mL})$ and $\mathrm{P}(3 \mathrm{HB}) / \mathrm{FF}(54 \mathrm{mg} / \mathrm{mL})$ films using fetal bovine serum $(\mathrm{FBS})(n=3$; error bars $= \pm \mathrm{SD})$.

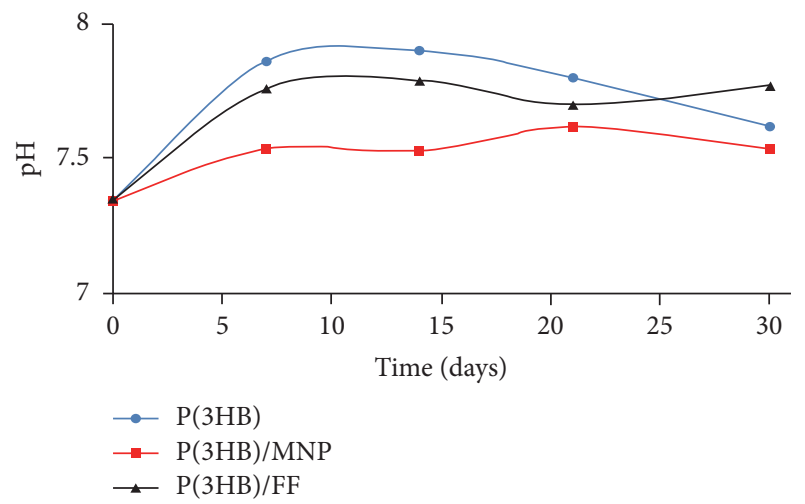

Figure 10: Change in $\mathrm{pH}$ of SBF with time of immersion of $\mathrm{P}(3 \mathrm{HB})$, $\mathrm{P}(3 \mathrm{HB}) / \mathrm{MNP}(54 \mathrm{mg} / \mathrm{mL})$, and $\mathrm{P}(3 \mathrm{HB}) / \mathrm{FF}(54 \mathrm{mg} / \mathrm{mL})$ composite films.

same trend of increase in total protein adsorption compared to neat $\mathrm{P}(3 \mathrm{HB})$.

3.8. $\mathrm{pH}$ Changes of the SBF Solution Immersed with Neat $\mathrm{P}(3 \mathrm{HB})$ and the Composites. The $\mathrm{pH}$ of the immersed SBF for neat $\mathrm{P}(3 \mathrm{HB})$ and composite materials exhibited initial increase in value and later decreased with increase in the incubation time. However, the $\mathrm{pH}$ of the SBF solution with neat $\mathrm{P}(3 \mathrm{HB})$ film increased mostly after 7 days of incubation followed by $\mathrm{P}(3 \mathrm{HB}) / \mathrm{FF}$ and $\mathrm{P}(3 \mathrm{HB}) / \mathrm{MNP}$, respectively (Figure 10).

3.9. Cytocompatibility Study of Neat $P(3 H B), P(3 H B) / M N P$, and $P(3 H B) / F F$ Composites. The magnetic composites developed in this work were further assessed for cytocompatibility, an essential property for a tissue engineering scaffold. The increased hydrophilicity of the composites and the $\mathrm{micro/nanosurfaces} \mathrm{was} \mathrm{expected} \mathrm{to} \mathrm{allow} \mathrm{cell} \mathrm{adhesion,} \mathrm{pro-}$ liferation, and functioning of human osteoblasts. The human osteoblast-like cell line MG-63 was used as the prototype for osteoblastic cells. This human osteosarcoma MG-63 cell

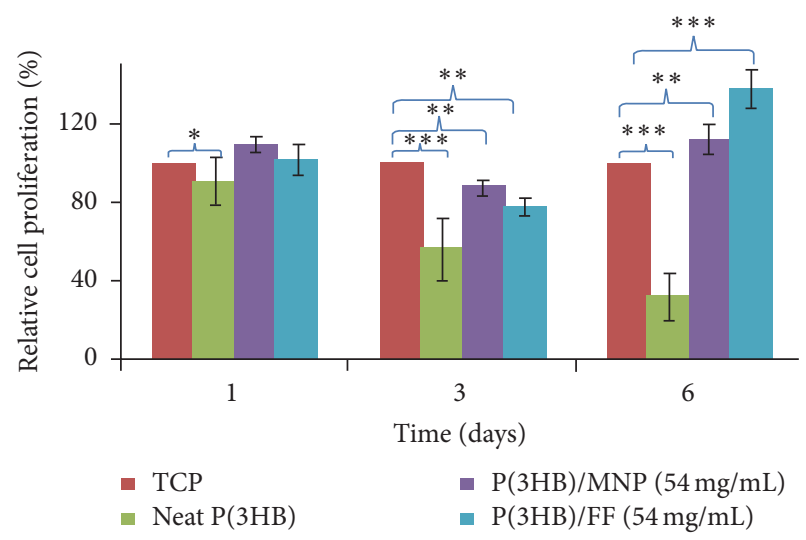

FIgure 11: Cell proliferation study using Alamar blue assay for TCP, neat $\mathrm{P}(3 \mathrm{HB}), \mathrm{P}(3 \mathrm{HB}) / \mathrm{MNP}(54 \mathrm{mg} / \mathrm{mL})$, and $\mathrm{P}(3 \mathrm{HB}) / \mathrm{FF}$ $(54 \mathrm{mg} / \mathrm{mL})$ composite film performed on days 1,3 , and 6 . All samples are tested relative to the control set at $100 \%(n=3$, error $=$ $\pm \mathrm{SD}$, significant at ${ }^{*} p=0.05,{ }^{* *} p<0.01$, and $\left.{ }^{* * *} p<0.05\right)$.

line has been extensively characterized and validated as a model to test biocompatibility of various materials intended for bone tissue engineering [16]. Despite being a tumour cell line, MG-63 exhibits many osteoblastic traits, including high levels of 1,25-dihydroxyvitamin $\mathrm{D}_{3}\left(1,25-(\mathrm{OH})_{2} \mathrm{D}_{3}\right)$ responsive alkaline phosphatase activity and the inhibition of cell proliferation after $1,25-(\mathrm{OH})_{2} \mathrm{D}_{3}$ treatment. Studies have also shown its ability to synthesize osteocalcin and collagen type 1, which are characteristic of bone-forming cells. Tissue culture plastic (TCP) was used as the positive control on which all cell types are known to attach and proliferate.

3.9.1. Cell Proliferation Study. The in vitro biocompatibility of the composite materials was investigated using the MG63 cell line described above. A histogram representing cell proliferation and growth on the composite films produced by incorporation of either $14 \mathrm{mg} \mathrm{MNP}$ or ferrofluid to the polymer matrix is shown in Figure 11. The result shows that the cells proliferated and grew well on all the tested samples. The cell proliferation on neat $\mathrm{P}(3 \mathrm{HB})$ was found to be lower than that on TCP and the composite materials. In contrast with the control, the MG- 63 cells proliferated better on the $\mathrm{P}(3 \mathrm{HB}) / \mathrm{FF}$ composite material. Thus, a significant difference $(p<0.01)$ was found in cell proliferation between the $\mathrm{P}(3 \mathrm{HB}) / \mathrm{MNP}$ and $\mathrm{P}(3 \mathrm{HB}) / \mathrm{FF}$ composite films. At day 6 of the cell proliferation study, the cell proliferation on $\mathrm{P}(3 \mathrm{HB}) / \mathrm{MNP}$ and $\mathrm{P}(3 \mathrm{HB}) / \mathrm{FF}$ composite specimens was much better as compared to that on neat $\mathrm{P}(3 \mathrm{HB})$ films.

3.9.2. Total Protein Production by Human Osteosarcoma MG63 Cell Lines on the $P(3 H B) / M N P$ and $P(3 H B) / F F$ Composites. The total protein production by the MG- 63 cell lines on the composite specimens was investigated from the supernatant of the cells grown in both osteogenic media and normal growth media at different time points. Since total protein production by the cells correlates with mineralisation by the growing cells, the protein produced by the growing MG-63 


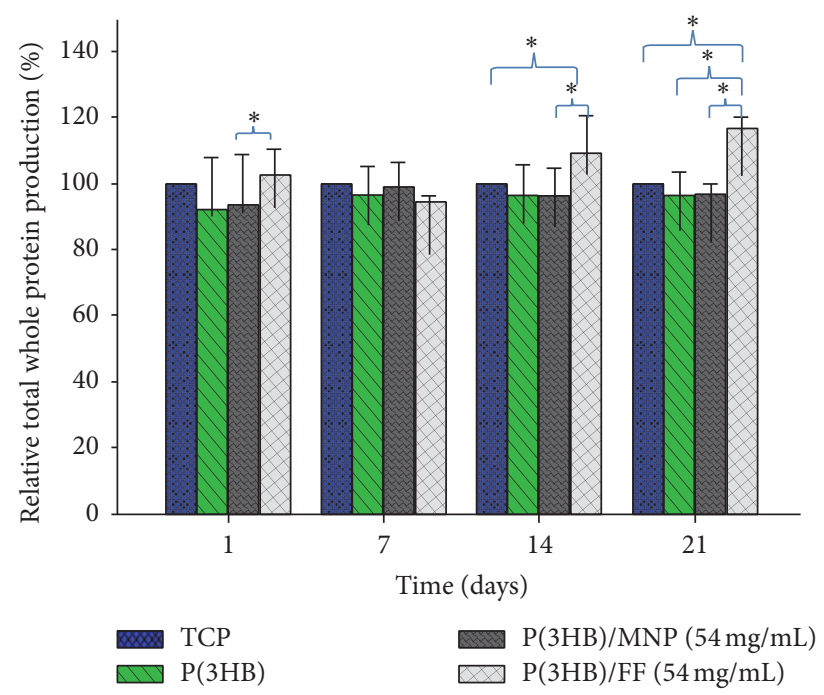

Figure 12: Protein production by MG-63 cells on TCP, P(3HB), $\mathrm{P}(3 \mathrm{HB}) / \mathrm{MNP}(54 \mathrm{mg} / \mathrm{mL})$, and $\mathrm{P}(3 \mathrm{HB}) / \mathrm{FF}(54 \mathrm{mg} / \mathrm{mL})$, grown in osteogenic media at different time points. Samples were measured relative to the control set at $100 \%$ (TCP) $(n=3$, error $= \pm$ SD, and $\left.{ }^{*} p<0.01\right)$.

cells on days 1, 7, 14, and 21 was quantified using commercial Qubit Protein Assay Kits purchased from Invitrogen ${ }^{\mathrm{TM}}$.

Figures 12 and 13 show the histogram of the total protein produced by the growing cells on the test materials at different time points. Total protein produced was measured for MG63 cells grown on the TCP (control), neat $\mathrm{P}(3 \mathrm{HB})$, and the composite specimens grown in both osteogenic and normal growth media. A statistical difference $(p<0.01)$ was found between total protein produced by the MG-63 cells cultured in osteogenic media and those cultured in normal growth media. Furthermore, statistical difference $(p<0.01)$ was found between total protein produced by the MG-63 cells grown on $\mathrm{P}(3 \mathrm{HB}) / \mathrm{FF}$ and $\mathrm{P}(3 \mathrm{HB}) / \mathrm{MNP}$ substrates and TCP after 14 days of culture.

3.10. Cell Morphology. Figure 14 shows MG-63 cells grown on TCP, neat $\mathrm{P}(3 \mathrm{HB}), \mathrm{P}(3 \mathrm{HB}) / \mathrm{MNP}$, and $\mathrm{P}(3 \mathrm{HB}) / \mathrm{FF}$ films on day 1 and day 7. Both $\mathrm{P}(3 \mathrm{HB}) / \mathrm{MNP}$ and $\mathrm{P}(3 \mathrm{HB}) / \mathrm{FF}$ composite films contained $14 \mathrm{mg}$ of either magnetic particles or magnetic fluid. The figure highlights the attachment of cells on the surface of the materials. Also, MG-63 cells were found to be flattened on the magnetic composite films as observed on either the tissue culture plastic or the $\mathrm{P}(3 \mathrm{HB})$ films indicating that the composite materials were conducive for cell adhesion and proliferation. At day 7, the MG-63 cells spread very well throughout the surface of both TCP and the test materials forming a monolayer on the surfaces.

\section{Discussion}

Recently, much effort is being dedicated towards the development of sustainable technologies for the fabrication of customized tissue engineering scaffolds with reproducible internal morphology that can ensure enhanced oxygen and

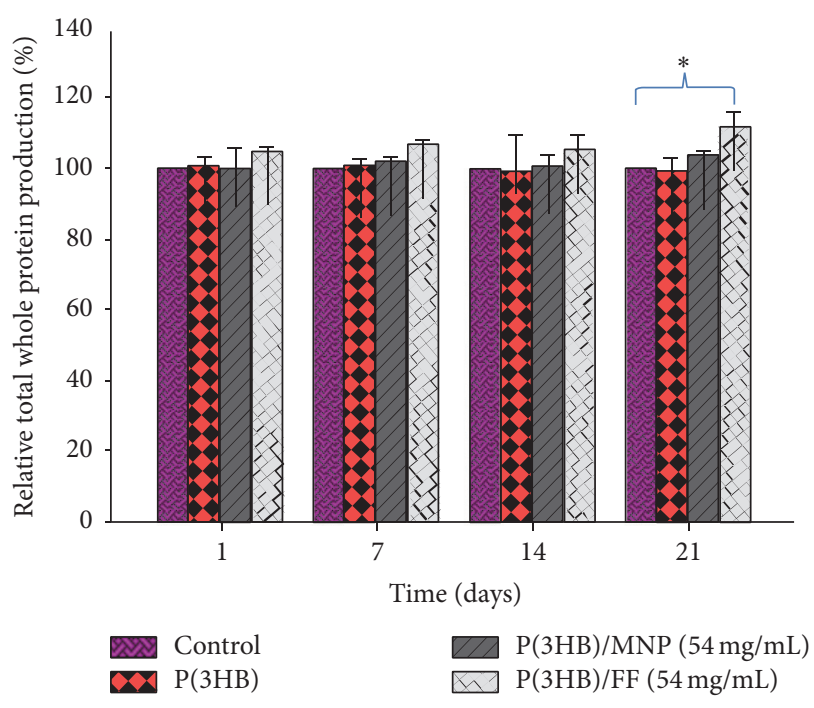

FIGURE 13: Protein production by MG-63 cell lines on the control, $\mathrm{P}(3 \mathrm{HB}), \mathrm{P}(3 \mathrm{HB}) / \mathrm{MNP}(54 \mathrm{mg} / \mathrm{mL})$, and $\mathrm{P}(3 \mathrm{HB}) / \mathrm{FF}(54 \mathrm{mg} / \mathrm{mL})$, with normal growth media at different time points. Samples were measured relative to the control (TCP) set at $100 \%(n=3$, error bars $= \pm \mathrm{SD}$, and $\left.{ }^{*} p<0.01\right)$.

nutrient transport throughout the scaffold. Among the successfully developed scaffolds, there are still limitations and difficulties in controlling cell differentiation and angiogenesis as well as obtaining stable scaffold implantation in the pathological site. Hence, the conceptual provision of a scaffold that can not only provide architectural frame work and physicomechanical support, but also enhance cell growth, proliferation, and differentiation in vivo has been proposed in this study. Two different forms of magnetite (MNPs and $\mathrm{FF}$ ) were incorporated into polymeric $\mathrm{P}(3 \mathrm{HB})$ in order to achieve these objectives. The SEM imaging confirmed the $2 \mathrm{D}$ composite materials to have micro/nanosurfaces. Misra et al. have observed similar micro/nanosurfaces on the addition of Bioglass $^{\circledR}$ in the $\mathrm{P}(3 \mathrm{HB})$ matrix to produce $\mathrm{P}(3 \mathrm{HB}) /$ Bioglass $2 \mathrm{D}$ and $3 \mathrm{D}$ composites [17]. The crystals found on the surface of the $\mathrm{P}(3 \mathrm{HB}) / \mathrm{MNP}$ composite were the magnetic particles incorporated within the polymer matrix. The well dispersed nanoparticles and their aggregates are known to be very useful in the provision of large surface area for protein adsorption and cellular adhesions. Also, the presence of the highly distributed magnetic particles and aggregates of MNPs is expected to aid in reducing the hydrophobic properties of the polymer matrix. Electron diffraction patterns of the composite materials confirmed the presence of the magnetic nanoparticles and ferrofluid as well as the homogenous distributions of aggregates of the incorporated materials throughout the composite specimens. The diffraction rings of magnetite and polymeric $\mathrm{P}(3 \mathrm{HB})$ shown in Figure 2 indicated that aggregates of magnetite nanoparticles and ferrofluid were randomly distributed in the composite films $(\mathrm{P}(3 \mathrm{HB}) / \mathrm{MNP}$ and $\mathrm{P}(3 \mathrm{HB}) / \mathrm{FF})$. This observation is in agreement with the crystallographic features observed in the XRD spectra of the composite samples (figure not shown). The homogenous distribution of the 

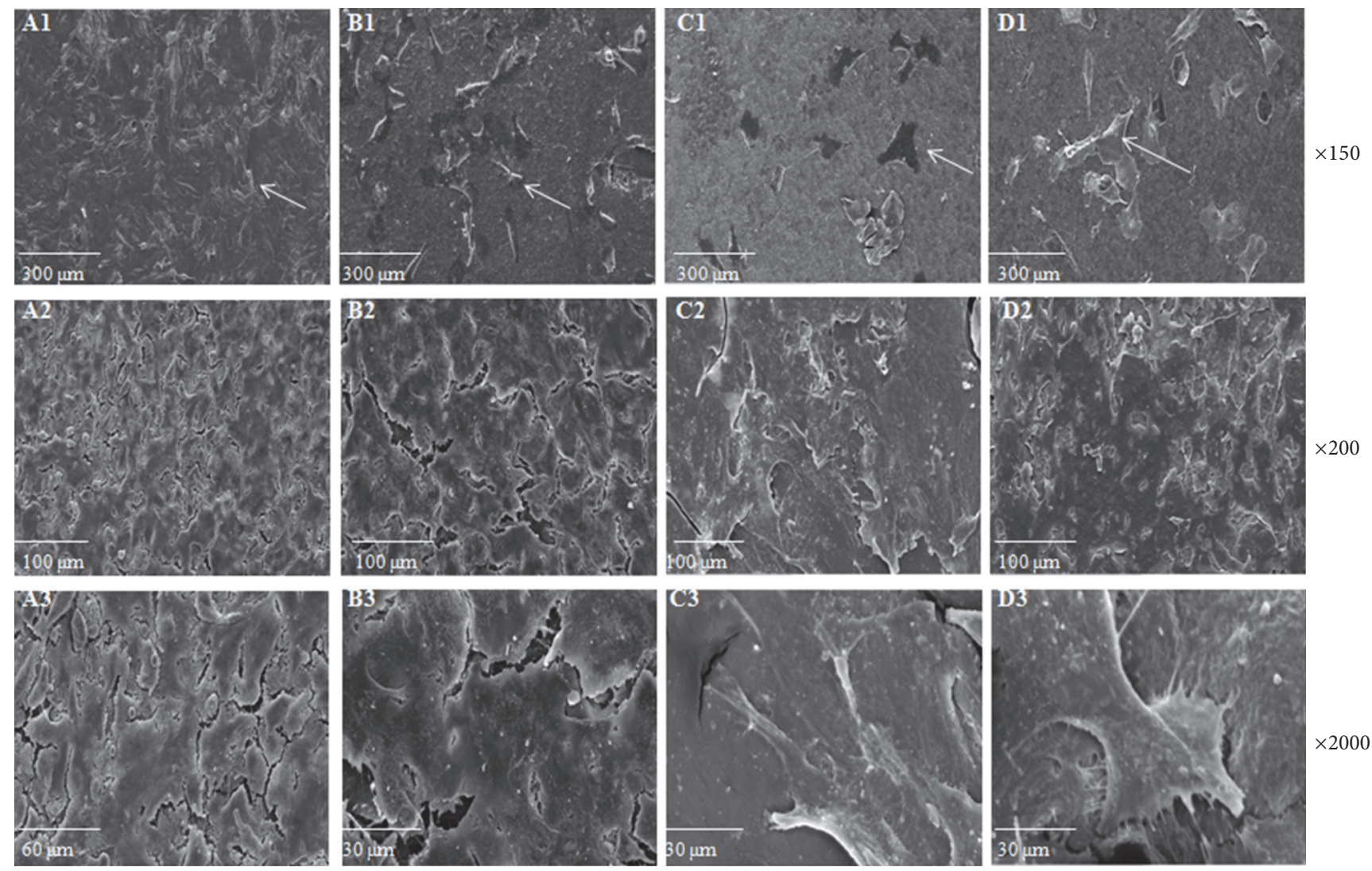

Figure 14: SEM images of MG-63 cells growing on (A1) TCP; (B1) neat P(3HB); (C1) P(3HB)/MNP; and (D1) P(3HB)/FF film on day 1. SEM images of MG-63 cells growing on (A2) tissue culture plastic; (B2) neat $\mathrm{P}(3 \mathrm{HB})$; (C2) $\mathrm{P}(3 \mathrm{HB}) / \mathrm{MNP}$; and (D2) $\mathrm{P}(3 \mathrm{HB}) / \mathrm{FF}$ film at day 7. Higher magnification of MG-63 cells growing at day 7 revealing healthy cells that flattened out and attached on the surface of the materials and on each other forming a monolayer on (A3) tissue culture plastic; (B3) neat $\mathrm{P}(3 \mathrm{HB})$; (C3) $\mathrm{P}(3 \mathrm{HB}) / \mathrm{MNP}$; and $(\mathrm{D} 3) \mathrm{P}(3 \mathrm{HB}) / \mathrm{FF}$ films. Arrows highlight cells attached on the materials.

incorporated materials in the composites is necessary to obtain composites with high mechanical performance and uniform degradation kinetics throughout the materials.

The hysteresis loops of the $\mathrm{P}(3 \mathrm{HB}) /$ magnetic nanoparticles and $\mathrm{P}(3 \mathrm{HB}) /$ magnetic fluid composites almost saturate at $\pm 1 \mathrm{~T}$ without coercivity or remnant magnetization. This behaviour is typical for paramagnetic or superparamagnetic materials. As shown in Figures 3 and 4, all the magnetic hysteresis loops passed through the grid origin. In addition, it was also shown that the residual magnetization $\left(\sigma_{r}\right)$ of all the particles was zero. This shows that both the magnetite nanoparticles and ferrofluid composites have good superparamagnetism (i.e., small superparamagnetic iron oxide particles $<20 \mathrm{~nm}$ forming $\approx 100 \mathrm{~nm}$ large aggregates). Also, comparing their saturation magnetization $\left(\sigma_{s}\right)$, it is apparent that $\sigma_{s}$ increased as the amount of magnetite nanoparticles in the scaffold increased. The absence of a coercive field at temperatures close to $300 \mathrm{~K}$ is characteristic of superparamagnetic material and therefore confirmed that both $\mathrm{P}(3 \mathrm{HB}) / \mathrm{MNP}$ and $\mathrm{P}(3 \mathrm{HB}) / \mathrm{FF}$ composites had superparamagnetic properties [18]. For a superparamagnetic material, the resulting magnetic scaffold may reach appropriate magnetization values (i.e., up to $15 \mathrm{emu} \mathrm{g}^{-1}$ at $10 \mathrm{kOe}$ ) upon application of an external magnetic field. These magnetization values can, in future, be used to attract cells or other bioagents bound to the MNPs [19]. Also, the superparamagnetic properties confirm the ability of the scaffold to be magnetized by applying a magnetic field without any remnant magnetization once the field is removed $[1,20,21]$. The hysteresis loop of neat $\mathrm{P}(3 \mathrm{HB})$ was found to be composed of two magnetic phases: first corresponding to the paramagnetic or superparamagnetic phase and second belonging to the diamagnetic phase, as is evident from the profile of the hysteresis curve, at lower and higher applied fields, respectively. The appearance of weak paramagnetic or superparamagnetic phase could have resulted from contaminations during sample preparation. As expected, neat $\mathrm{P}(3 \mathrm{HB})$ has a very low maximum magnetization $\left(M_{\max +}\right)$ at $1 \mathrm{~T}(0.004 \mathrm{emu} / \mathrm{g})$ when compared to the composite materials. Hence, neat $\mathrm{P}(3 \mathrm{HB})$ can be confirmed to have negligible magnetic properties and would not produce any effects when an external magnetic field is applied.

The result of the DMA analysis shown in Figure 5 demonstrated that the mechanical properties of $\mathrm{P}(3 \mathrm{HB})$ increased with the addition of either magnetic nanoparticles or ferrofluid. The increase in the mechanical properties of the composite materials was possibly due to enhanced crystallinity which in turn could be due to spherulite formation. Stronger intermolecular interaction within the lamellae of the 
spherulite could account for the increased Young's modulus achieved in the composite materials. Similar trends have been observed for tensile strength, yield stress, and toughness by Ehrenstein and Theriault on isotactic polypropylene [22]. Hence, the addition of MNP and ferrofluid had a positive effect on enhancing Young's modulus of the composite materials. Misra et al., Chen and Wang, and Wang et al. have reported similar increase in Young's modulus on the addition of bioceramics to a polymer matrix [12, 23, 24]. Enhanced mechanical performances of the composite materials are highly desirable in the context of bone tissue engineering, a high load bearing application as compared to soft tissues [25].

The important observations made from the dynamic modulus (storage and loss modulus) analysis on the materials are firstly the addition of either MNPs or FF effectively increased the storage modulus of the polymer, as can be seen in Table 1. It is possible that the storage modulus increase was due to partial immobilisation of the polymer chains as a result of adsorption onto the filler surface. Secondly, the addition of the magnetic materials also resulted in an increase in $\tan \delta$; hence, the damping capacity of the material increased. Such behaviour can occur due to the introduction of new damping mechanisms that are not present in the neat polymer. Some of the possible explanations for this increase are (a) friction within the MNPs where particles touch one another as in weak agglomerates, (b) friction between $\mathrm{P}(3 \mathrm{HB})$ and MNPs where there is essentially no adhesion at the interface, and (c) excess damping ( $\tan \delta$, ratio of the loss to storage modulus) in the polymer near the interface because of induced thermal stresses or changes in polymer conformation due to incorporation of filler. Finally the dynamic modulus studies revealed that the storage modulus was found to increase with the addition of either MNPs or FF. On increasing the temperature, the storage modulus was found to decrease more in the composite materials than in the neat $\mathrm{P}(3 \mathrm{HB})$ sample. This further confirmed a weak polymer/MNP interfacial interaction.

The FTIR spectra of the composite materials actually showed modified adsorption peaks in shape and intensity when compared to the characteristic peaks of neat $\mathrm{P}(3 \mathrm{HB})$. This could be due to hydrogen and ionic bond interactions between the polymeric matrix and the magnetite. Millan et al. have observed similar weak hydrogen and strong ionic bonds during the preparation of maghemite polymer nanocomposite [26]. The result of the analysis indicated that the crystallisation of the polymer matrix was affected by the addition/introduction of the fillers. This has therefore further strengthened the possibility that changes in the crystalline properties of the polymer microstructure occurred as a result of the crystallisation process of the nanocomposite material on introduction of the fillers.

The surface property of biomaterials plays an important role in their performance in a biological environment. Much research has been conducted to analyse the effects of hydrophobicity and hydrophilicity on biological responses (i.e., protein adsorption and cell adhesion). Improved surface wettability generally improves the interactions between the composite materials and the cells and results in controlled cellular adhesion and maintenance of differentiated phenotypic expression [27]. Many researchers including Li et al. have investigated the effect of addition of inorganic materials to a biodegradable polymer matrix. Li et al. in their investigations with wollastonite composite scaffold observed that the incorporation of wollastonite to the $\mathrm{P}(3 \mathrm{HB}-\mathrm{co}-3 \mathrm{HV})$ polymer matrix improved the hydrophilicity of the composite [28]. In this study, the introduction of either magnetic nanoparticles or ferrofluid to the $\mathrm{P}(3 \mathrm{HB})$ polymer matrix significantly improved the hydrophilicity of the composite material. The MNPs were washed with water and acetone after preparation and later dispersed in chloroform and used for composite fabrication. This explains why the MNPs are hydrophilic and subsequently reduced the hydrophobicity of the composites upon their incorporation. In the case of the FF, though, after washing with water and methanol after preparation, the FF was coated with oleic acid before heating under reflux. The coating with oleic acid reduced the hydrophilicity of the FF, hence the slight reduction in hydrophilicity after incorporation in the composite when compared to the neat $\mathrm{P}(3 \mathrm{HB})$ and composite containing MNPs.

Detailed knowledge of the relationship between the surface properties of a biomaterial and its ability to absorb protein when exposed to a protein-containing medium is very important in the application of a specific biomaterial in tissue regeneration. Apart from the very important physicomechanical properties, a biomaterial should be able to support cell adhesion, proliferation, and differentiation and these can be achieved with the help of protein layers which provide support for the anchorage of cells onto a biomaterial. When a biomaterial is exposed to cells suspended in a culture medium supplemented with FBS, protein in the serum is rapidly adsorbed onto the surface of the biomaterial prior to cell adhesion. The adsorption of cell adhesive serum proteins, such as fibronectin and vitronectin, plays a critical role in cell adhesion onto a biomaterial surface and subsequently determines cell adhesion behaviour [29]. The adsorption of serum protein onto the surface of the $2 \mathrm{D}$ magnetic nanocomposite was possibly due to the synergetic contribution of increased hydrophilicity, surface chemistry, and surface charge provided by the incorporated magnetic materials. Also, the larger surface area provided by the magnetic nanoparticles possibly played an important role in the increased protein adsorption observed on the composite material.

Previous research has shown that very hydrophobic materials such as polytetrafluoroethyene (PTFE) with a water contact angle between $105^{\circ}$ and $116^{\circ}$ inhibit cellular adsorption. In contrast, hydrophilic materials such as tissue culture plastic are known to support cellular adhesion [30]. The observations made in this study using the Alamar blue assay showed that the cells were able to attach to the surface of the materials (i.e., TCP, neat $\mathrm{P}(3 \mathrm{HB}), \mathrm{P}(3 \mathrm{HB}) / \mathrm{MNP}$, and $\mathrm{P}(3 \mathrm{HB}) / \mathrm{FF})$ on the first day of the assay. This was most likely due to the absorbed protein layer which in turn enabled anchorage for the cells. However, as the incubation time increased, it was found that cell proliferation on the neat $\mathrm{P}(3 \mathrm{HB})$ film reduced as compared to the cell proliferation on the control and the composite materials. This could be explained based on the possibility that the absorbed 
protein on the surface of the neat $\mathrm{P}(3 \mathrm{HB})$ interacted with the hydrophobic surface of the neat $\mathrm{P}(3 \mathrm{HB})$ in a manner that led to changes in the protein conformation and thus resulted in reduced access of the cells to the ligand moieties needed for integrin binding and cell attachment. Cell proliferation was found to increase more with time on the magnetic nanocomposites than on TCP and the neat $\mathrm{P}(3 \mathrm{HB})$. This is probably due to the ability of the magnetic composite material to provide large surface area and good surface chemistry which enhanced protein adsorption onto the surface of the materials. This result was in agreement with the water contact angles and protein adsorption measured, therefore confirming that the magnetic nanocomposites are excellent biomaterials for cellular attachment and proliferation. The fact that the magnetic materials supported cell attachment and proliferation showed that they are highly cytocompatible and can be safely used to improve mechanical properties as well as provide nanostructured surfaces for cell adhesion and proliferation in tissue regeneration.

It has been suggested that increased bone formation leads to increased total protein production by the bone cells [31]. The result of the investigation depicted in Figure 14 shows that neither MNPs nor ferrofluid had any adverse effect towards proteins secreted by the cells.

Gopferich has observed that $\mathrm{pH}$ is an important factor that influences the rate of hydrolysis during the degradation of the polymers [32]. The $\mathrm{pH}$ of SBF in which both types of samples were immersed increased a little above the initial $\mathrm{pH}$ of the buffer (7.35). Since the degradation product of $\mathrm{P}(3 \mathrm{HB})$ is a 3-hydroxy butyric acid and the $\mathrm{pKa}$ of 3-hydroxybutyric acid is 4.70 , at $\mathrm{pH} 7.35$, the 3-hydroxybutyric acid will be in the anionic form, that is, the basic form, leading to a rise in $\mathrm{pH}$ of the SBF. However, once the concentration of 3hydroxybutyric acid reaches beyond a critical concentration due to the degradation of the polymer, the SBF is no longer able to maintain the $\mathrm{pH}$ at 7.35 and the $\mathrm{pH}$ falls slightly due to the acidic nature of 3-hydroxybutyric acid.

In vivo, biomaterial surfaces are usually coated by components present in the extracellular fluid. However, the adsorption of extracellular fluid to the biomaterial is largely dependent on the surface chemistry, charge, wettability, and free energy of the biomaterial which is regulated by the microstructural features on the biomaterial surface. The spreading and proliferation observed after day 1 is possibly due to material surface-protein interactions, micro/nanosurfaces, and chemistry which favoured adhesion, proliferation, and differentiation of cells.

Cell responses to micro/nanosurfaces are expressed in their ability to attach, proliferate, and differentiate [33]. Ordinarily, it is difficult to determine which structures are responsible for individual phenotypic traits expressed by cells grown on different materials. The cells were found to have anchored to the surfaces of the materials tested, with flattened morphology that were most often characterized by extended filopodia reaching out to neighbouring cells. It is possible that favourable nanostructural surfaces of the materials provided by the fillers could have influenced the spreading of the filopodia by the cells. Boyan et al. have suggested that architectural features present on biomaterial surface could have influence on the morphology of the cells [34]. Such architectural features include micro rough surfaces and shorter peak-to-peak distances (Figure 1) of pores comparable to the length of the cell body. Boyan et al. later concluded that cells growing on biomaterial surfaces with these features are prone to exhibit cuboidal shape while anchoring to the surface with long dendritic filopodia [34]. Brunette et al. on the other hand observed that cells spread out and lay flat, resulting in a fibroblastic appearance on smooth surfaces $[35,36]$. However, the cells seeded onto both TCP and the 2D test materials conform to the characteristic behaviour of osteoblasts on smooth surfaces. In addition, the cells grown on the magnetic composite materials produced thread-like denticles which are crucial for cell to cell communications.

\section{Conclusions}

This work presents an in-depth analysis of the potential application of $\mathrm{P}(3 \mathrm{HB}) / \mathrm{MNP}$ and $\mathrm{P}(3 \mathrm{HB}) / \mathrm{FF}$ nanocomposites for bone tissue repair. The favourable thermomechanical properties in combination with the biocompatibility achieved in this work provided evidence of the future potential of the $\mathrm{P}(3 \mathrm{HB}) / \mathrm{MNP}$ and $\mathrm{P}(3 \mathrm{HB}) / \mathrm{FF}$ composites in bone tissue engineering. Further studies using these promising materials will involve 3D scaffold fabrication and detailed in vivo work which will allow the generation of preclinical data. Hence, in conclusion, the results obtained in this work confirm the huge potential of the $\mathrm{P}(3 \mathrm{HB}) / \mathrm{MNP}$ and $\mathrm{P}(3 \mathrm{HB}) / \mathrm{FF}$ composites in the development of bone tissue repair implants to meet the current unmet needs in magneto-mechanical stimulation/activation of cells, magnetic cell-seeding, and controlled cell proliferation and differentiation in bone repair.

\section{Competing Interests}

The authors declare that they have no competing interests.

\section{Acknowledgments}

This work was partly supported by the Ministry of Education, Youth and Sports of the Czech Republic (Project no. LO1305 and the Research Infrastructure NanoEnviCz, Project no. LM2015073) and by the Czech Science Foundation (Project no. 14-11516S). The authors also thank Jiři Tuček for the SQUID measurements and Ondřej Malina for technical assistance (both are from Regional Centre of Advanced Technologies and Materials, Palacký University, Olomouc, Czech Republic). Dr. Everest Akaraonye acknowledges the University of Westminster Scholarship Committee for the award of the Cavendish Scholarship which financially supported him during this work.

\section{References}

[1] N. Bock, A. Riminucci, C. Dionigi et al., "A novel route in bone tissue engineering: magnetic biomimetic scaffolds," Acta Biomaterialia, vol. 6, no. 3, pp. 786-796, 2010. 
[2] J. L. Corchero, J. Seras, E. García-Fruitós, E. Vazquez, and A. Villaverde, "Nanoparticle-assisted tissue engineering," Nanobiotech, pp. 13-15, 2010.

[3] D. K. Kim, M. Toprak, M. Mikhailova et al., "Surface modification of superparamagnetic nanoparticles for in-vivo biomedical applications," Materials Research Society Symposium Proceedings, vol. 704, pp. 369-374, 2002.

[4] K. Shimizu, A. Ito, J.-K. Lee et al., "Construction of multilayered cardiomyocyte sheets using magnetite nanoparticles and magnetic force," Biotechnology and Bioengineering, vol. 96, no. 4, pp. 803-809, 2007.

[5] H. Akiyama, A. Ito, M. Sato, Y. Kawabe, and M. Kamihira, "Construction of cardiac tissue rings using a magnetic tissue fabrication technique," International Journal of Molecular Sciences, vol. 11, no. 8, pp. 2910-2920, 2010.

[6] A. Ito, E. Hibino, C. Kobayashi et al., "Construction and delivery of tissue-engineered human retinal pigment epithelial cell sheets, using magnetite nanoparticles and magnetic force," Tissue Engineering, vol. 11, no. 3-4, pp. 489-496, 2005.

[7] A. Ito, M. Hayashida, H. Honda et al., "Construction and harvest of multilayered keratinocyte sheets using magnetite nanoparticles and magnetic force," Tissue Engineering, vol. 10, no. 5-6, pp. 873-880, 2004.

[8] E. Akaraonye, C. Moreno, J. C. Knowles, T. Keshavarz, and I. Roy, "Poly(3-hydroxybutyrate) production by Bacillus cereus SPV using sugarcane molasses as the main carbon source," Biotechnology Journal, vol. 7, no. 2, pp. 293-303, 2012.

[9] R. Massart, "Preparation of aqueous magnetic liquids in alkaline and acidic media," IEEE Transactions on Magnetics, vol. 17, no. 2, pp. 1247-1248, 1981.

[10] H. Kiwada, J. Sato, S. Yamada, and Y. Kato, "Feasibility of magnetic liposomes as a targeting device for drugs," Chemical and Pharmaceutical Bulletin, vol. 34, no. 10, pp. 4253-4258, 1986.

[11] T. Kokubo, N. Takashi, and M. Fumiaki, "Apatite formation on ceramics, metals and polymers induced by a $\mathrm{CaO}-\mathrm{SiO}_{2}$ based glass in a simulated body fluid," in Bioceramics, W. Bonfield, G. W. Hastings, and K. E. Tanner, Eds., Oxford, UK, ButterworthHeinemann, 1991.

[12] S. K. Misra, P. C. P. Watts, S. P. Valappil, S. R. P. Silva, I. Roy, and A. R. Boccaccini, "Poly(3-hydroxybutyrate)/Bioglass ${ }^{\circledR}$ composite films containing carbon nanotubes," Nanotechnology, vol. 18, no. 7, Article ID 075701, 2007.

[13] J. Rich, J. Tuominen, J. Kylmä, J. Seppälä, S. N. Nazhat, and K. E. Tanner, "Lactic acid based PEU/HA and PEU/BCP composites: dynamic mechanical characterization of hydrolysis," Journal of Biomedical Materials Research Part B: Applied Biomaterials, vol. 63, no. 3, pp. 346-353, 2002.

[14] I. M. Ward, Mechanical Properties of Solid Polymers, John Wiley \& Sons, New York, NY, USA, 1985.

[15] A. Padermshoke, Y. Katsumoto, H. Sato, S. Ekgasit, I. Noda, and Y. Ozaki, "Melting behavior of poly(3-hydroxybutyrate) investigated by two-dimensional infrared correlation spectroscopy," Spectrochimica Acta-Part A: Molecular and Biomolecular Spectroscopy, vol. 61, no. 4, pp. 541-550, 2005.

[16] N. Price, S. P. Bendall, C. Frondoza, R. H. Jinnah, and D. S. Hungerford, "Human osteoblast-like cells (MG63) proliferate on a bioactive glass surface," Journal of Biomedical Materials Research, vol. 37, no. 3, pp. 394-400, 1997.

[17] S. K. Misra, D. Mohn, T. J. Brunner et al., "Comparison of nanoscale and microscale bioactive glass on the properties of

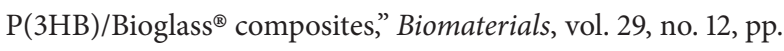
$1750-1761,2008$

[18] A. Akbarzadeh, M. Samiei, and S. Davaran, "Magnetic nanoparticles: preparation, physical properties, and applications in biomedicine," Nanoscale Research Letters, vol. 7, article 144, 2012.

[19] A. Gloria, T. Russo, U. D’Amora et al., "Magnetic poly( $(\varepsilon-$ caprolactone)/iron-doped hydroxyapatite nanocomposite substrates for advanced bone tissue engineering," Journal of the Royal Society, Interface, vol. 10, no. 80, 2013.

[20] Q. A. Pankhurst, J. Connolly, S. K. Jones, and J. Dobson, "Applications of magnetic nanoparticles in biomedicine," Journal of Physics D: Applied Physics, vol. 36, no. 13, pp. R167-R181, 2003.

[21] A. Tampieri, T. D’Alessandro, M. Sandri et al., "Intrinsic magnetism and hyperthermia in bioactive Fe-doped hydroxyapatite," Acta Biomaterialia, vol. 8, no. 2, pp. 843-851, 2012.

[22] G. W. Ehrenstein and R. P. Theriault, Polymeric Materials: Structure, Properties, Applications, Hanser, Munich, Germany, 2001.

[23] U. Chen and M. Wang, "Production and evaluation of biodegradable composite based on PHB-PHV copolymer," Biomat, vol. 23, no. 13, pp. 2631-2639, 2002.

[24] M. Wang, L. L. Hench, and W. Bonfield, "Bioglass ${ }^{\circledR} /$ high density polyethylene composite for soft tissue applications: preparation and evaluation," Journal of Biomedical Materials Research, vol. 42, no. 4, pp. 577-586, 1998.

[25] T. Russo, A. Gloria, V. D’Antò et al., "Poly( $\varepsilon$-caprolactone) reinforced with sol-gel synthesized organic-inorganic hybrid fillers as composite substrates for tissue engineering," Journal of Applied Biomaterials and Biomechanics, vol. 8, no. 3, pp. 146152,2010

[26] A. Millan, F. Palacio, A. Falqui et al., "Maghemite polymer nanocomposites with modulated magnetic properties," Acta Materialia, vol. 55, no. 6, pp. 2201-2209, 2007.

[27] N. Galego, C. Rozsa, R. Sánchez, J. Fung, A. Vázquez, and J. S. Tomás, "Characterization and application of $\operatorname{poly}(\beta-$ hydroxyalkanoates) family as composite biomaterials," Polymer Testing, vol. 19, no. 5, pp. 485-492, 2000.

[28] J. Li, H. Yun, Y. Gong, N. Zhao, and X. Zhang, "Effects of surface modification of poly (3-hydroxybutyrate-co-3hydroxyhexanoate) (PHBHHx) on physicochemical properties and on interactions with MC3T3-E1 cells," Journal of Biomedical Materials Research Part A, vol. 75, no. 4, pp. 985-989, 2005.

[29] F. Grinnell and M. K. Feld, "Fibronectin adsorption on hydrophilic and hydrophobic surfaces detected by antibody binding and analyzed during cell adhesion in serum-containing medium," Journal of Biological Chemistry, vol. 257, no. 9, pp. 4888-4893, 1982.

[30] M. Chen, P. O. Zamora, P. Som, L. A. Peña, and S. Osaki, "Cell attachment and biocompatibility of polytetrafluoroethylene (PTFE) treated with glow-discharge plasma of mixed ammonia and oxygen," Journal of Biomaterials Science, Polymer Edition, vol. 14, no. 9, pp. 917-935, 2003.

[31] T. Paz, K. Wade, T. Kiyoshima et al., "Tissue and bone cellspecific expression of bone sialprotein is directed by a $9.0 \mathrm{~kb}$ promoter intranspegenic mice," Matrix Biology, vol. 24, no. 5, pp. 341-352, 2005.

[32] A. Gopferich, "Mechanisms of polymer degradation and erosion," Biomat, vol. 17, no. 2, pp. 103-114, 1996.

[33] D. M. Brunette, "Spreading and orientation of epithelial cells on grooved substrata," Experimental Cell Research, vol. 167, no. 1, pp. 203-217, 1986. 
[34] B. D. Boyan, T. W. Hummert, K. Kieswetter, D. Schraub, D. D. Dean, and Z. Schwartz, "Effect of titanium surface characteristics on chondrocytes and osteoblasts in vitro," Cells and Materials, vol. 5, no. 4, pp. 323-335, 1995.

[35] D. M. Brunette, "The effects of implant surface topography on the behavior of cells," The International Journal of Oral \& Maxillofacial Implants, vol. 3, no. 4, pp. 231-246, 1988.

[36] B. D. Boyan, S. Lossdörfer, L. Wang et al., "Osteoblasts generate an osteogenic microenvironment when grown on surfaces with rough microtopographies," European Cells and Materials, vol. 6, pp. 22-27, 2003. 

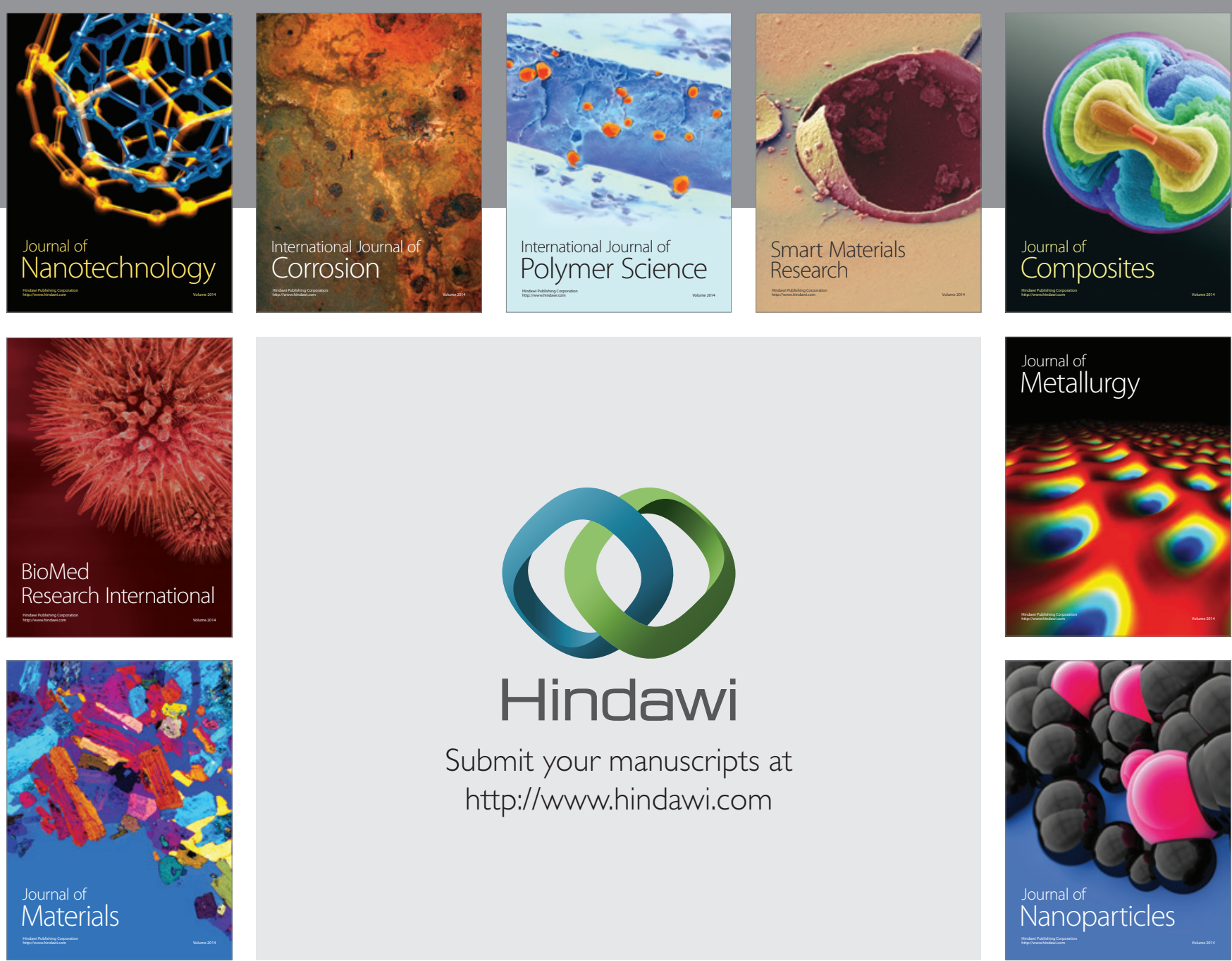

\section{Hindawi}

Submit your manuscripts at

http://www.hindawi.com

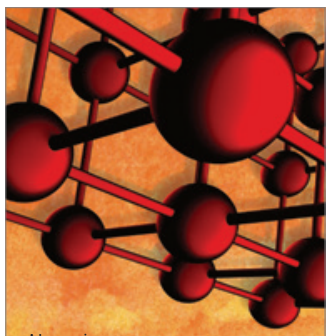

Materials Science and Engineering
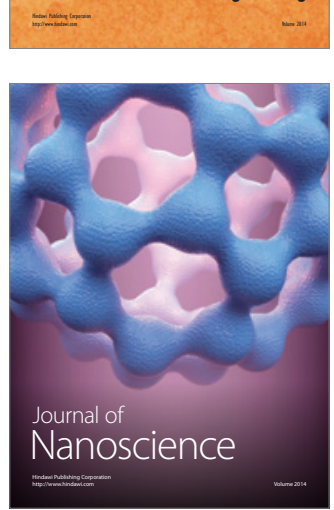
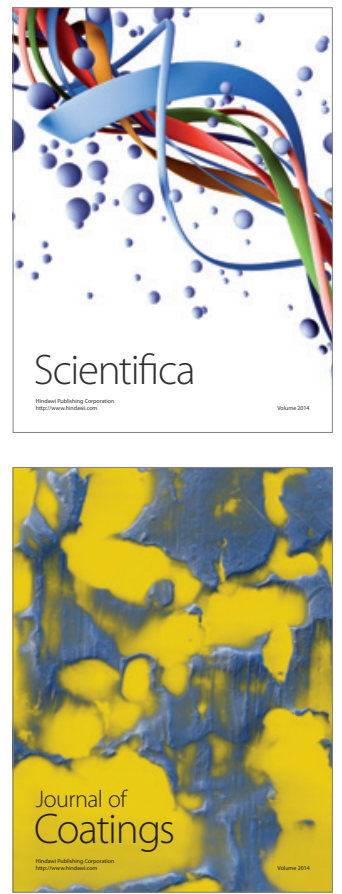
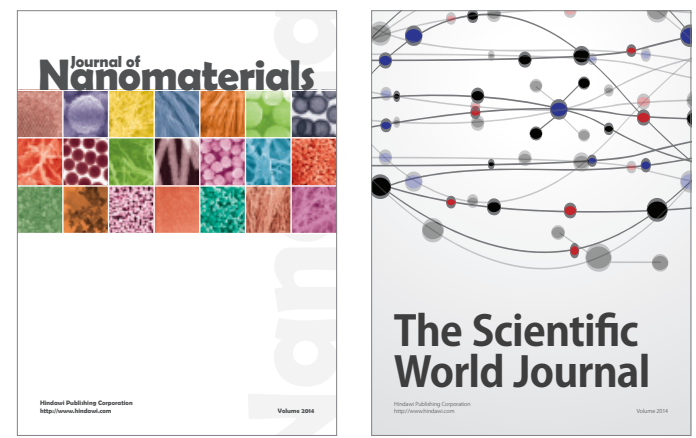

The Scientific World Journal
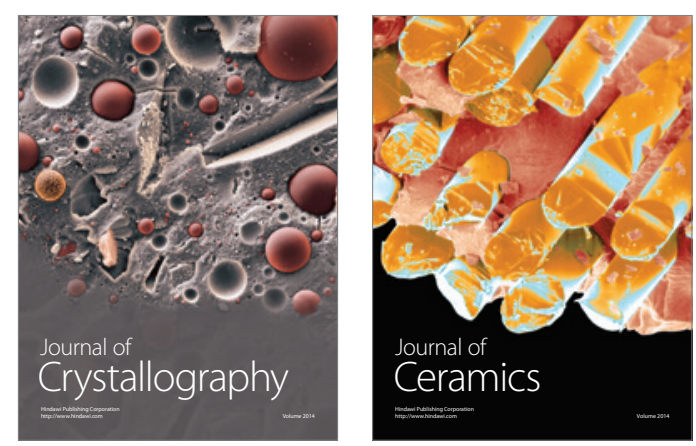
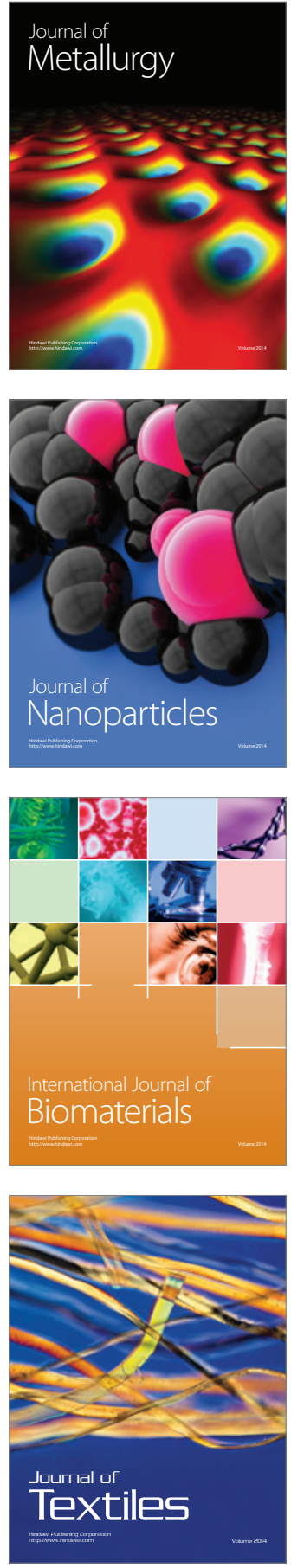